\title{
Residence times of groundwater and nitrate transport in coastal aquifer systems: Daweijia area, northeastern China
}

\author{
Dongmei Han ${ }^{\mathrm{a}, \mathrm{b}, *}$, Guoliang Cao ${ }^{\mathrm{b}, \mathrm{c}}$, James McCallum ${ }^{\mathrm{b}, \mathrm{d}}$, Xianfang Song ${ }^{\mathrm{a}}$ \\ ${ }^{a}$ Key Laboratory of Water Cycle E Related Land Surface Processes, Institute of Geographic Sciences and Natural Resources Research, Chinese Academy of Sciences, Beijing 100101, China \\ ${ }^{b}$ National Centre for Groundwater Research and Training, Flinders University, GPO Box 2100, Adelaide, SA 5001, Australia \\ c Center for Water Research, College of Engineering, Peking University, Beijing 100871, China \\ d School of the Environment, Flinders University, GPO Box 2100, Adelaide, SA 5001, Australia
}

\section{H I G H L I G H T S}

- Examine high nitrate contents in the coastal carbonate aquifer of northeast China

- Estimate renewal rates and mean residence times of groundwater in coastal aquifers

- Evaluate the relation between groundwater age distribution and nitrate transport

- Propose potential pollution patterns of nitrate distribution in the coastal aquifer

- Identify anthropogenic input mainly responsible for increasing groundwater salinity

\section{A R T I C L E I N F O}

\section{Article history:}

Received 17 March 2015

Received in revised form 6 July 2015

Accepted 8 August 2015

Available online 28 August 2015

Editor: D. Barcelo

\section{Keywords:}

Coastal carbonate aquifer

Seawater intrusion

Groundwater mean residence time

Nitrate transport

Anthropogenic contamination

\begin{abstract}
A B S T R A C T
Groundwater within the coastal aquifer systems of the Daweijia area in northeastern China is characterized by a large of variations (33-521 mg/L) in $\mathrm{NO}_{3}^{-}$concentrations. Elevated nitrate concentrations, in addition to seawater intrusion in the Daweijia well field, both attributable to anthropogenic activities, may impact future watermanagement practices. Chemical and stable isotopic $\left(\delta^{18} \mathrm{O}, \delta^{2} \mathrm{H}\right)$ analysis, ${ }^{3} \mathrm{H}$ and CFCs methods were applied to provide a better understanding of the relationship between the distribution of groundwater mean residence time (MRT) and nitrate transport, and to identify sources of nitrate concentrations in the complex coastal aquifer systems. There is a relatively narrow range of isotopic composition (ranging from -8.5 to $-7.0 \%$ ) in most groundwater. Generally higher tritium contents observed in the wet season relative to the dry season may result from rapid groundwater circulation in response to the rainfall through the preferential flow paths. In the well field, the relatively increased nitrate concentrations of groundwater, accompanied by the higher tritium contents in the wet season, indicate the nitrate pollution can be attributed to domestic wastes. The binary exponential and piston-flow mixing model (BEP) yielded feasible age distributions based on the conceptual model. The good inverse relationship between groundwater MRTs (92-467 years) and the $\mathrm{NO}_{3}^{-}$concentrations in the shallow Quaternary aquifers indicates that elevated nitrate concentrations are attributable to more recent recharge for shallow groundwater. However, there is no significant relationship between the MRTs (8-411 years) and the $\mathrm{NO}_{3}^{-}$concentrations existing in the carbonate aquifer system, due to the complex hydrogeological conditions, groundwater age distributions and the range of contaminant source areas. Nitrate in the groundwater system without denitrification effects could accumulate and be transported for tens of years, through the complex carbonate aquifer matrix and the successive inputs of nitrogen from various sources.
\end{abstract}

(c) 2015 Elsevier B.V. All rights reserved.

\section{Introduction}

Increasing groundwater salinization has become one of the major issues in many coastal aquifers, impairing groundwater utilization for various purposes. This salinization may also be occurring alongside significant

* Corresponding author at: Key Laboratory of Water Cycle \& Related Land Surface Processes, Institute of Geographic Sciences and Natural Resources Research, Chinese Academy of Sciences, Beijing 100101, China. increases in population and an increased water demand for industry, agriculture and tourism development. These factors have increased the pressure on freshwater supply in coastal areas. The deterioration of coastal aquifers due to salinization may endanger future water exploitation (Vengosh et al., 1999). There are a number of mechanisms that have the potential to lead to salinity in coastal regions: (i) agricultural return flows from local groundwater extraction (Bouchaou et al., 2008; Cruz-Fuentes et al., 2014); (ii) a high degree of evaporation in residual saline water (McCaffrey et al., 1987; Han et al., 2014); (iii) recharge/leakage 
of imported salt water from the sea for fishing industries (Chang and Li, 2011); (iv) seawater intrusion/tidal flat/sea level rising (Werner et al., 2013); (v) saltwater upconing from underlying aquifers (Barlow, 2003; Szynkiewicz et al., 2008) or downward movement of shallow saline groundwater from upper aquifers under extensive pumping (Vengosh and Ben-Zvi, 1994; Guo et al., 1995; Cary et al., 2015); (vi) mixing modern recharged water with the palaeo-seawater (brines) (Yechieli et al., 1992; Han et al., 2011, 2012); (vii) sewage effluents (Vengosh et al., 1998); and (viii) water-rock interaction (Jones et al., 1999; Vengosh et al., 2007; de Montety et al., 2008; Mongelli et al., 2013; Merchán et al., 2015). For a reliable water management/protection plan and to prevent further deterioration, it is essential to study the major geochemical processes that modify hydrochemical compositions of waters salinized by seawater intrusion and to elucidate the salinity sources and flow paths that exist in the coastal aquifer.

Carbonate aquifers are often a prolific groundwater source, and therefore much research has been dedicated to karst aquifers. These aquifers are characterized by complex hydrogeological conditions. This study will focus on the coastal aquifers in the Daweijia area of Dalian City, northeastern China, composed of upper Quaternary sediments and underlying Cambrian-Ordovician limestone and dolomitic limestone. Current studies on coastal carbonate aquifers throughout the world are undertaken in aquifers with lower nitrate concentrations than those of the Daweijia area. For example, $\mathrm{NO}_{3}^{-}$concentrations are less than $265 \mathrm{mg} / \mathrm{L}$ in groundwater from carbonate aquifers along the Mediterranean coast (Schiavo et al., 2006; Ghiglieri et al., 2012), less than $80 \mathrm{mg} / \mathrm{L}$ along the Gulf of Mexico (Andrews, 1994; Katz, 2004; Katz et al., 2004), and less than $20 \mathrm{mg} / \mathrm{L}$ along the Caribbean coast (Mutchler et al., 2007; Young et al., 2008; Null et al., 2014). In the coastal carbonate aquifer of the Daweijia area, $\mathrm{NO}_{3}^{-}$concentrations are characterized by high values reaching $521 \mathrm{mg} / \mathrm{L}$.

The major ion geochemistry of groundwater in coastal carbonate aquifers has been used in conjunction with multiple environmental tracers (e.g., $\delta^{18} \mathrm{O}, \delta^{2} \mathrm{H},{ }^{3} \mathrm{H}, \mathrm{CFCs},{ }^{14} \mathrm{C}$ ) for defining the recharge patterns of karst aquifers (including recharge origin, amount and distribution) (Jones et al., 2000; Horst et al., 2008; Charideh and Rahman, 2007; Frot et al., 2007; Murad et al., 2011; Khaska et al., 2013), building hydrogeological conceptual models (Falcone et al., 2008; Frondini, 2008; Long et al., 2008; Cerar and Urbanc, 2013), assessing possible anthropogenic influences on groundwater (Katz et al., 2004; Schiavo et al., 2006; El Yaoutia et al., 2009; Urresti-Estala et al., 2015) and estimating the residence time of younger groundwaters and flow rates (Katz, 2004; Horst et al., 2008; Ettayfi et al., 2012). In this study, we report the major chemical and $\delta^{18} \mathrm{O}-\delta^{2} \mathrm{H},{ }^{3} \mathrm{H}$ and CFC compositions of groundwater from the coastal aquifers in the Daweijia area of Dalian City, north-eastern China. We present a comprehensive overview of the environmental isotope variations in the groundwater of the Daweijia coastal area. This study aims to (i) estimate the groundwater mean residence times in this area, (ii) provide a better understanding of the relationship between groundwater age distributions and nitrate transport in the complex coastal aquifer systems, and (iii) evaluate the contribution to the modification of groundwater quality from anthropogenic inputs and seawater intrusion.

\section{Study area}

The Daweijia area $\left(39^{\circ} 09^{\prime}-39^{\circ} 13^{\prime} \mathrm{N}\right.$ and $\left.121^{\circ} 37^{\prime}-121^{\circ} 47^{\prime} \mathrm{E}\right)$ that forms the northern part of Dalian City is located in the coastal basin of LiaoDong Peninsula, northeast China. The coastal basin opens in the west towards the Bohai Sea, about $45 \mathrm{~km}$ north of Dalian City. The study area lies within a catchment with an area of approximately $66 \mathrm{~km}^{2}$. The area is characterized by an oceanic and temperate monsoon climate, with a mean annual rainfall of $600 \mathrm{~mm}$ and an average annual temperature of $10.5^{\circ} \mathrm{C}$. Daweijia River is the largest stream in this area and runs ephemerally through the whole region from east to west. The land use and the extent of the coastal basin can be seen from Fig. 1.
The area is a typical fault and fold belt, including two groups of faults: NW normal faults (F1 and F2, Fig. 2) and NE reverse faults (F3 and F4, Fig. 2), and an asymmetrical NW-syncline. Two hydrological units constitute the major water reservoirs in this study area. They include the shallow Quaternary aquifer (QA) and the deep carbonate rock aquifer (COA). Quaternary sediments ranging in thickness from 10 to $40 \mathrm{~m}$ are composed of sand, silt and gravel. The underlying carbonated rock aquifers (COA) are hosted by Sinian, middle Cambrian to middle Ordovician limestone, which is characterized by uneven karstification. Karst is well developed in the synclinal axis and near the impermeable boundary. The COA is semiconfined due to the occurrence of a clay loam layer. However, the variations of groundwater level are in accordance with that in the QA suggesting strong hydraulic connection (Yang, 2011). Groundwater in this complex hydrogeological system is recharged from vertical infiltration of precipitation, the lateral influx of karst groundwater, and inflow from the east. Prior to development (before the 1960s), groundwater discharged by means of springs along the coastline and flowed into the Bohai Sea (Jin and Wu, 1990). The Daweijia well field was established near the fault zone (F1, in Fig. 2) in 1969 and was a major supply of groundwater to Dalian City in the 1970s (Lü, 1980). The main production wells include CG2, CG3, CG7, and CG17 (Fig. 2) with depths of 90-120 m. In the dry season, the Quaternary aquifer readily becomes de-watered. The unplanned groundwater pumping that commenced in the 1970s has broken the natural hydrodynamic balance in the coastal aquifers, producing continuous groundwater level decline in the central area of the Daweijia well field. The hydrogeologic cross-sections (Fig. 3) show the groundwater flow patterns in these coastal aquifers.

Seawater intrusion, mainly caused by unplanned groundwater exploitation, was observed for the first time in this coastal area as early as 1964 (the earliest in China). Due to the intensive abstraction, groundwater levels fell to -9 m.a.s.l in the vicinity of the well field in June 1980 , and resulted in gradual, serious seawater intrusion, leading to groundwater salinization (Yang, 2011). Groundwater levels appeared to rise ( 2 m.a.s.l in the central of well field) in June 2009, after cessation of groundwater exploitation in 2001 (Song, 2013). Fan (1984) described the relationship between seawater intrusion and groundwater hydraulic dynamics and calculated the amount of extracted groundwater resources. Jin and Wu (1990) evaluated the distribution and features of seawater intrusion and the vertical heterogeneity of the carbonate aquifers by using electrical logging of well fluid, and determined the optimal pumping position. Wu (1990) established a groundwater management model, taking the maximum quantity of groundwater exploitation as an objective function, for optimizing the abstraction plan in the carbonate aquifer system. Zhao (1991) delineated the characteristics of karstified development in this area and discussed the relationship between seawater intrusion and the distribution of groundwater depression. Wu et al. (1994) analyzed the patterns of seawater intrusion and proposed controlling countermeasures. Nevertheless, few studies have identified a hydrogeological conceptual model, geochemical processes and the anthropogenic impact on groundwater salinization in Chinese coastal carbonate aquifers. Two tasks not undertaken in previous studies are 1) to establish the reliable conceptual model of the groundwater flow systems in this coastal area, and 2) to determine whether the current salinity distribution is the result of long-term (natural) processes or recent (anthropogenic) changes.

\section{Sampling and analytical techniques}

\subsection{Sampling and chemical analysis}

68 water samples (65 groundwater samples from pumping wells and 3 seawater samples) were taken during four sampling campaigns (November 2005, June 2006, July 2007, and August 2010) along an approximately $10 \mathrm{~km}$ cross-section in the Daweijia area of Dalian City. The wells are production wells for irrigation and domestic supply. The 

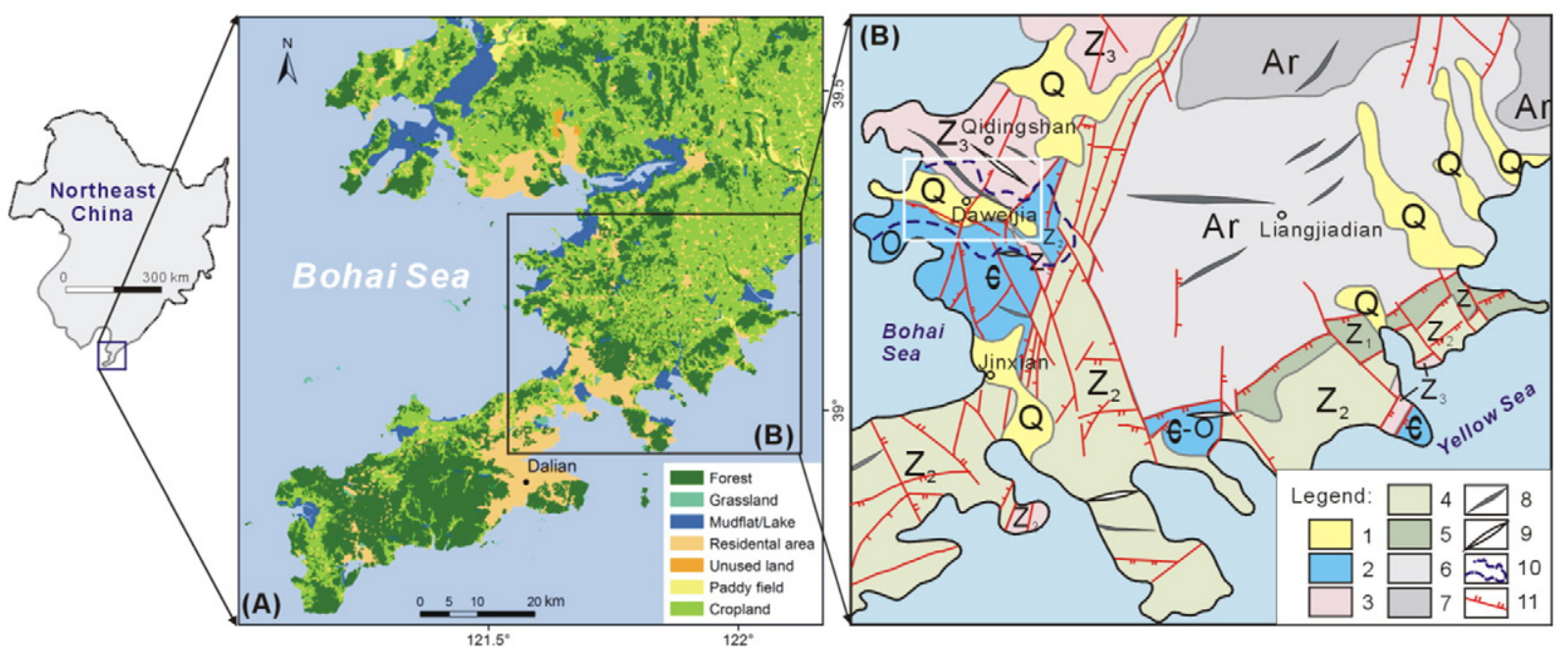

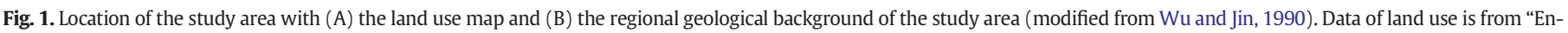

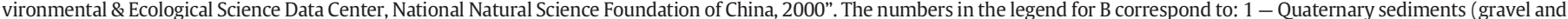

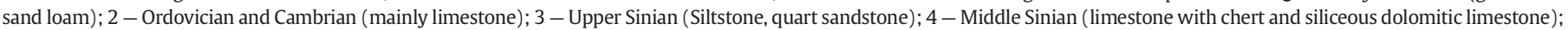

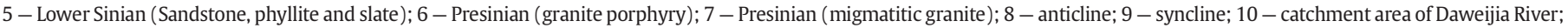
11 - Fault. The white box in Fig. 1.B represents the location of Fig. 2.

depth of the screened intervals of these wells range mostly from $65-100 \mathrm{~m}$ below ground surface (Table 1 ). The mean depth of screened intervals for the Quaternary aquifer and the carbonate aquifer is $15 \mathrm{~m}$ and $95 \mathrm{~m}$, respectively. All wells were purged for at least half an hour and water samples were collected after constant values of electrical conductivity (EC) and oxidation-reduction potential (ORP) had been established. Some parameters (e.g. pH, EC and temperature) were measured in the field using a portable WM-22EP meter at each well. Seawater samples were collected directly offshore. Samples were analyzed for chemical, multiple isotopic, CFCs and tritium contents. Anions and cations of water samples were filtered using $0.45 \mu \mathrm{m}$ millipore syringe filters and stored in new rinsed HDPE bottles at $4{ }^{\circ} \mathrm{C}$ in a cool room. For cation analysis, the samples were acidified to a $\mathrm{pH}<2$ with ultrapure
$\mathrm{HNO}_{3}$. Given that $\mathrm{pH}$ values of most groundwater samples range from 7.0 to 8.5 , the major $\mathrm{C}$ species is dissolved as $\mathrm{HCO}_{3}^{-}$, indicating that using $\mathrm{HCO}_{3}^{-}$rather than total DIC will not influence the results. The $\mathrm{HCO}_{3}^{-}$concentrations were determined as total alkalinity and were titrated with $0.22 \mathrm{~N} \mathrm{H}_{2} \mathrm{SO}_{4}$ within $24 \mathrm{~h}$ of sampling. Major chemical analyses was undertaken at the Laboratory of Physics and Chemistry, Institute of Geographic Sciences and Natural Resources Research, Chinese Academy of Sciences (CAS). The major hydrochemical ions were analyzed with the ion chromatograph (SHIMADZU). The ion balance errors of hydrochemical analyses were generally within $\pm 6 \%$ for non-diluted samples and $\pm 15 \%$ for diluted samples that showed higher salinisation. The groundwater samples have been classified as either fresh (TDS $<1 \mathrm{~g} / \mathrm{L})$ or brackish $(1 \mathrm{~g} / \mathrm{L}<\mathrm{TDS}<10 \mathrm{~g} / \mathrm{L})$.

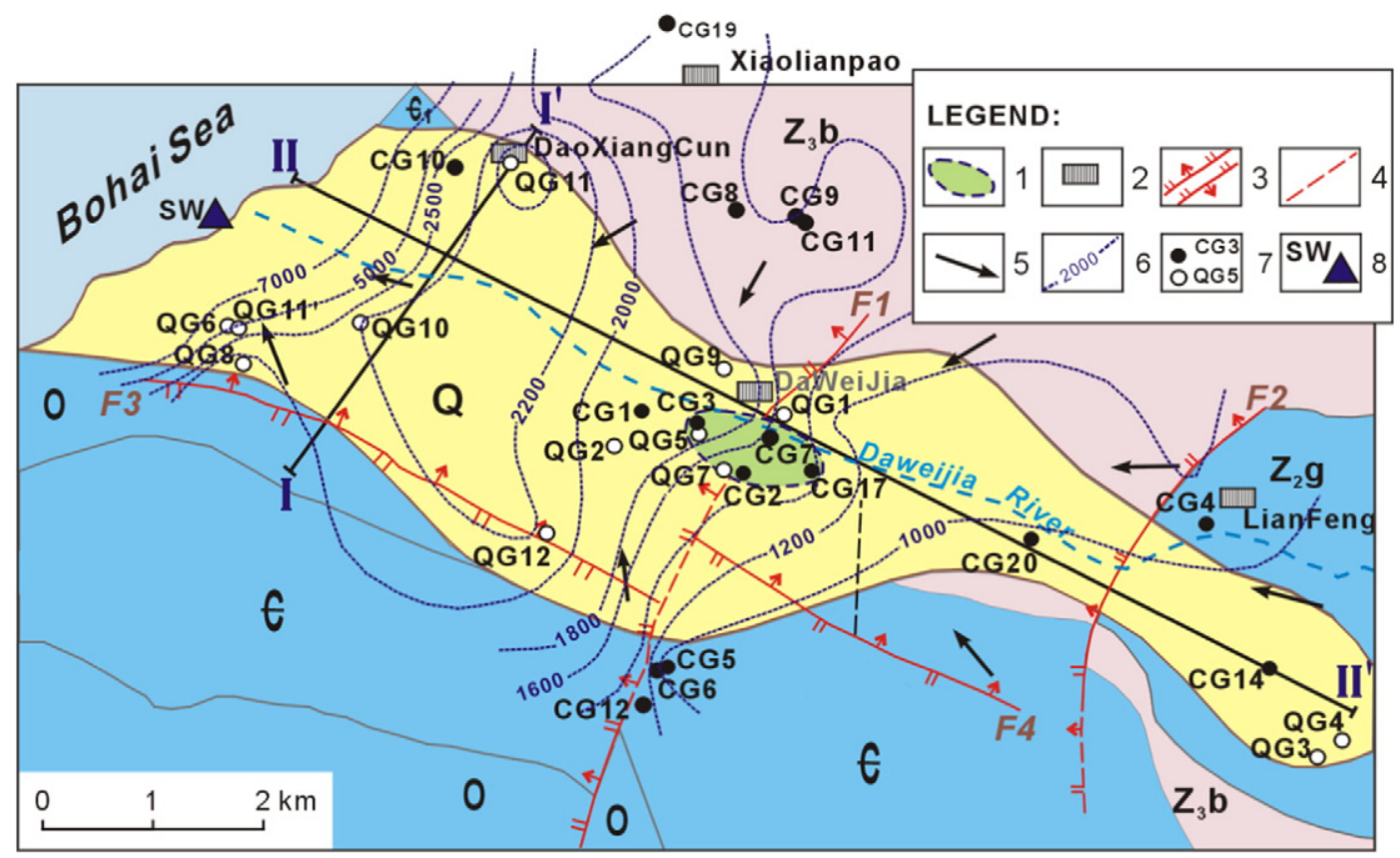

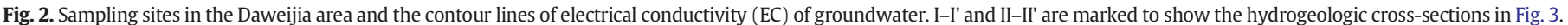

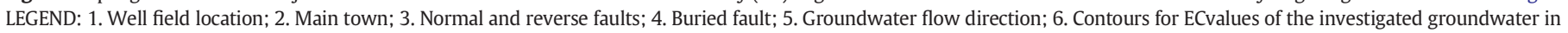
August. 2010; 7. Sampling wells: @ from carbonated aquifer (depth $>80 \mathrm{~m}$ ), $\bigcirc$ from Quaternary aquifer (depth $<40 \mathrm{~m}$ ); 8 . Seawater sampling site. 


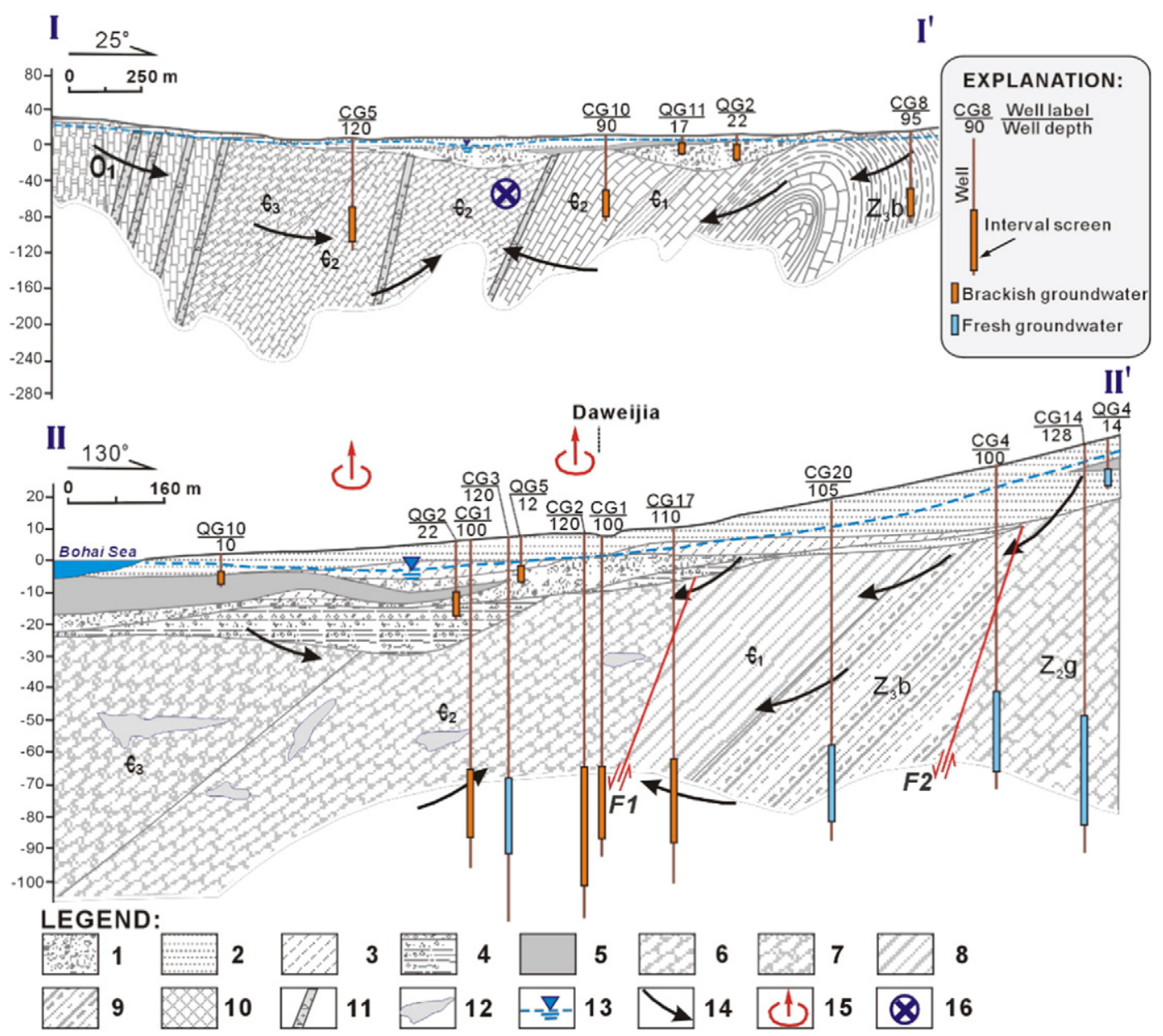

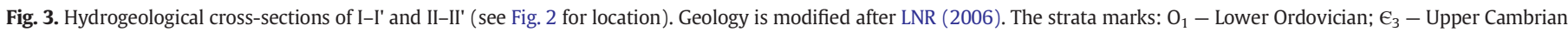

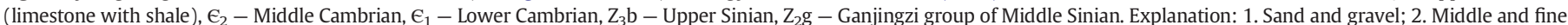

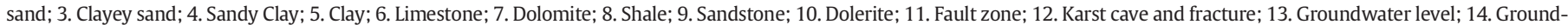
water flow direction; 15 . Concentrated groundwater exploitation zone; 16 . Outflow perpendicular to this plane.

As a conservative tracer, $\mathrm{Cl}^{-}$concentration can be used to estimate the fraction of seawater $\left(F_{S W}\right)$ in the collected groundwater samples:

$F_{S W}=\frac{[C l]_{\text {sample }}-[C l]_{\text {fresh }}}{[C l]_{\text {sea }}-[C l]_{\text {fresh }}}$.

Based on conservative mixing of salt water and fresh water, the chemical reactions occurring during the fresh- and salt-water interaction can be deduced (Appelo and Postma, 2005) for a better understanding of the hydrochemical processes in the coastal aquifer. Here, given the two end-member water samples (mixing between rainwater as fresh water and seawater as salt water), the concentration of an ion $i$ can be calculated by:

$m_{i, \text { mix }}=F_{S W} \cdot m_{i, \text { sea }}+\left(1-F_{S W}\right) \cdot m_{i, f r e s h}$

where $m_{i}$ is the concentration of the ion $i$ (in meq/L); $F_{S W}$ is the fraction of seawater in the collected groundwater; and mix, sea and fresh refer to the conservative mixture and the end members of seawater and freshwater, respectively. The change of the concentration due to reactions, $m_{i, \text { react }}$ can be obtained by:

$m_{i, \text { react }}=m_{i, \text { sample }}-m_{i, \text { mix }}$

where $m_{i \text {, sample }}$ is the measured concentration of ion $i$ in the water sample. For example, it can be expressed as $\mathrm{Na}_{\text {react, }} \mathrm{Ca}_{\text {react }}, \mathrm{Mg}_{\text {react }}$, and $\mathrm{SO}_{4, \text { react. }}$
The stable isotopes ${ }^{18} \mathrm{O}$ and ${ }^{2} \mathrm{H}$ and of the water samples were measured using mass spectrometry, with a Finnigan MAT253 after on-line pyrolysis and using a Thermo Finnigan TC/EA (Temperature Conversion Elemental Analyzer) method. This analysis was performed in the Institute of Geographic Sciences and Natural Resources Research, Chinese Academy of Sciences. The $\delta^{18} \mathrm{O}$ and $\delta^{2} \mathrm{H}$ values are expressed in conventional $\delta(\%)$ notation and calculated with respect to VSMOW and calibrated using IAEA standards. The analytical precision was $\pm 2 \%$ for $\delta^{2} \mathrm{H}$ and $\pm 0.5 \%$ for $\delta^{18} \mathrm{O}$. The results are shown in Table 1 .

\subsection{Chlorofluorocarbons (CFCS) analysis}

After the wells were purged, water samples were collected directly from the borehole using a Cu-tube sampling pipe for CFC analysis. This pipe was placed in the bottom of a $50 \mathrm{~mL}$ borosilicate ampoule, inside a beaker, and filled until no bubbles appeared in the ampoule. The sample was then sealed underwater to minimize atmospheric contamination, strictly following the protocols described by Busenberg and Plummer (1992). A total of 11 water samples were collected for CFCs (CFC-11, CFC-12 and CFC-113) analysis. The CFC contents were determined within 1 month of sample collection using a purge-and-trap gas chromatograph procedure with an electron capture detector working in constant-current mode (which has been described in detail by Oster et al., 1996), in the Laboratory of Groundwater Chronology, Institute of Geology and Geophysics, Chinese Academy of Sciences. The results reported by the laboratory were converted to equivalent air mixing ratios for comparison to atmospheric mixing ratios, following 
Table 1

Major ion concentrations and chemical-physical parameters.

\begin{tabular}{|c|c|c|c|c|c|c|c|c|c|c|c|c|c|c|c|c|}
\hline Sample & $\begin{array}{l}\text { Sampling } \\
\text { time }\end{array}$ & $\begin{array}{l}\text { Ele. } \\
\text { (m.a.s.l.) }\end{array}$ & $\begin{array}{l}\text { WellDepth } \\
(\mathrm{m})\end{array}$ & $\begin{array}{l}\text { Screen Interval } \\
(\mathrm{m})\end{array}$ & $\begin{array}{l}\mathrm{T} \\
\left({ }^{\circ} \mathrm{C}\right)\end{array}$ & $\mathrm{pH}$ & $\begin{array}{l}\text { EC } \\
\mu s / \mathrm{cm}\end{array}$ & $\begin{array}{l}\mathrm{Ca} \\
\mathrm{mg} / \mathrm{L}\end{array}$ & $\begin{array}{l}\mathrm{Mg} \\
\mathrm{mg} / \mathrm{L}\end{array}$ & $\begin{array}{l}\mathrm{Na} \\
\mathrm{mg} / \mathrm{L}\end{array}$ & $\begin{array}{l}\mathrm{K} \\
\mathrm{mg} / \mathrm{L}\end{array}$ & $\mathrm{Cl} \mathrm{mg/L}$ & $\begin{array}{l}\mathrm{SO} 4 \\
\mathrm{mg} / \mathrm{L}\end{array}$ & $\begin{array}{l}\mathrm{NO}_{3} \\
\mathrm{mg} / \mathrm{L}\end{array}$ & $\begin{array}{l}\mathrm{HCO}_{3} \\
\mathrm{mg} / \mathrm{L}\end{array}$ & $\begin{array}{l}\text { TDS } \\
\mathrm{mg} / \mathrm{L}\end{array}$ \\
\hline \multicolumn{17}{|c|}{ Fresh groundwater from the carbonate aquifers: } \\
\hline CG4 & Nov. 2005 & 25 & 100 & $70-95$ & 14.6 & 7.90 & 849 & 73.8 & 33.8 & 33.4 & 0.6 & 85.3 & 44.1 & 46.6 & 201.3 & 418.3 \\
\hline CG20 & Nov. 2005 & 19 & 105 & $76-101$ & 14.1 & 7.84 & 942 & 67.8 & 51.7 & 16.2 & 4.3 & 88.1 & 59.5 & & 238.3 & 406.6 \\
\hline CG4 & Jun. 2006 & 25 & 100 & $70-95$ & 14.9 & 7.26 & 860 & 101.7 & 43.1 & 48.9 & 0.8 & 87.7 & 51.5 & 49.2 & 360.5 & 563.1 \\
\hline CG8 & Jun. 2006 & 8 & 95 & $65-92$ & 18.6 & 6.37 & 1317 & 137.1 & 27.9 & 55.1 & 0.2 & 136.2 & 74.9 & 238.7 & 128.5 & 734.4 \\
\hline CG3 & Jul. 2007 & 12 & 110 & $72-98$ & 13.8 & 7.28 & 1703 & 140.0 & 43.4 & 108.9 & 2.2 & 351.3 & 92.8 & 76.2 & 240.8 & 935.2 \\
\hline CG4 & Jul. 2007 & 25 & 100 & $70-95$ & 14.8 & 7.23 & 863 & 84.9 & 28.1 & 30.8 & 1.1 & 103.3 & 47.6 & 48.1 & 249.4 & 468.6 \\
\hline CG8 & Jul. 2007 & 8 & 95 & $65-92$ & 12.9 & 7.34 & 1361 & 146.1 & 27.4 & 49.9 & 1.4 & 143.6 & 68.5 & 309.8 & 163.4 & 828.4 \\
\hline CG10 & Jul. 2007 & 5 & 90 & $59-86$ & 16.2 & 7.39 & 1413 & 149.0 & 30.2 & 61.4 & 4.2 & 202.5 & 110.8 & 181.7 & 213.6 & 846.5 \\
\hline CG12 & Jul. 2007 & 36 & 100 & $68-93$ & 15.0 & 6.65 & 1214 & 116.3 & 23.3 & 67.1 & 1.2 & 194.0 & 65.8 & 62.1 & 272.4 & 665.9 \\
\hline CG13 & Jul. 2007 & 5 & 100 & $74-92$ & 13.5 & 7.00 & 1560 & 202.6 & 36.9 & 48.0 & 0.8 & 152.0 & 174.5 & 161.8 & 375.6 & 964.4 \\
\hline CG14 & Jul. 2007 & 49 & 128 & $85-118$ & 14.8 & 7.35 & 755 & 76.4 & 24.3 & 19.7 & 1.5 & 65.2 & 44.3 & 65.2 & 220.8 & 406.9 \\
\hline CG3 & Aug. 2010 & 12 & 110 & $72-98$ & 19.3 & 7.31 & 986 & 115.8 & 37.8 & 47.2 & 1.5 & 209.5 & 93.8 & 60.3 & 282.8 & 707.2 \\
\hline CG4 & Aug. 2010 & 25 & 100 & $70-95$ & 16.1 & 7.23 & 1015 & 119.6 & 38.5 & 50.5 & 1.2 & 261.0 & 109.7 & 60.9 & 247.1 & 764.9 \\
\hline CG6 & Aug. 2010 & 34 & 120 & $75-112$ & 21.7 & 7.32 & 796 & 99.4 & 24.1 & 38.2 & 1.2 & 141.6 & 67.1 & 43.1 & 250.1 & 539.7 \\
\hline CG9 & Aug. 2010 & 9 & 100 & $68-92$ & 18.8 & 7.56 & 846 & 113.6 & 17.4 & 44.4 & 6.5 & 203.8 & 101.8 & 147.9 & 134.0 & 702.4 \\
\hline CG14 & Aug. 2010 & 49 & 128 & $85-118$ & 22.0 & 7.57 & 749 & 94.5 & 31.9 & 24.5 & 1.0 & 105.7 & 65.1 & 69.1 & 238.1 & 510.9 \\
\hline \multicolumn{17}{|c|}{ Brackish groundwater from the carbonate aquifers: } \\
\hline CG1 & Nov. 2005 & 10 & 100 & $71-93$ & 13.1 & 7.64 & 2900 & 219.0 & 91.9 & 228.1 & 2.6 & 556.2 & 117.2 & 112.9 & 132.0 & 1393.7 \\
\hline CG2 & Nov. 2005 & 14 & 120 & $72-107$ & 14.1 & 7.24 & 2400 & 269.1 & 61.7 & 180.2 & 2.7 & 318.4 & 120.0 & 260.1 & 159.8 & 1292.1 \\
\hline CG3 & Nov. 2005 & 12 & 110 & $72-98$ & 13.1 & 7.71 & 3340 & 261.3 & 103.7 & 318.6 & 1.0 & 726.5 & 99.9 & 32.6 & 248.8 & 1668.0 \\
\hline CG5 & Nov. 2005 & 33 & 120 & $75-112$ & 12.6 & 7.81 & 3030 & 145.4 & 42.7 & 213.8 & 0.0 & 573.6 & 98.5 & 52.4 & 60.1 & 1156.5 \\
\hline CG1 & Jun. 2006 & 10 & 100 & 71-93 & 14.9 & 7.31 & 2890 & 284.5 & 114.0 & 312.2 & 3.7 & 596.6 & 135.3 & 124.8 & 253.8 & 1698.1 \\
\hline CG2 & Jun. 2006 & 14 & 110 & $72-107$ & 13.2 & 7.04 & 2110 & 151.2 & 48.4 & 103.2 & 1.5 & 323.3 & 142.7 & 321.5 & 174.2 & 1178.9 \\
\hline CG3 & Jun. 2006 & 12 & 110 & $72-98$ & 13.2 & 7.22 & 2300 & 158.9 & 54.2 & 175.6 & 3.5 & 511.2 & 109.4 & 79.6 & 120.8 & 1152.8 \\
\hline CG7 & Jun. 2006 & 14 & 92 & $59-88$ & 13.3 & 6.80 & 2290 & 325.5 & 91.2 & 194.8 & 1.8 & 375.9 & 160.9 & 332.0 & 159.8 & 1562.0 \\
\hline CG9 & Jun. 2006 & 9 & 100 & $68-92$ & 13.0 & 7.07 & 2180 & 413.8 & 44.3 & 109.2 & 1.7 & 239.4 & 64.0 & 422.0 & 357.0 & 1472.9 \\
\hline CG1 & Jul. 2007 & 10 & 100 & $71-93$ & 15.8 & 7.07 & 2710 & 219.7 & 70.6 & 200.9 & 3.9 & 618.3 & 142.9 & 204.7 & 286.7 & 1604.3 \\
\hline CG2 & Jul. 2007 & 14 & 120 & $72-107$ & 13.8 & 7.02 & 2080 & 200.4 & 50.7 & 112.8 & 3.3 & 354.6 & 126.5 & 357.2 & 174.9 & 1292.9 \\
\hline CG5 & Jul. 2007 & 33 & 120 & $75-112$ & 15.8 & 7.05 & 2470 & 137.3 & 51.1 & 230.2 & 8.2 & 577.9 & 142.7 & 147.8 & 278.1 & 1434.2 \\
\hline CG7 & Jul. 2007 & 14 & 92 & $59-88$ & 13.8 & 6.80 & 2280 & 202.7 & 49.8 & 101.0 & 1.3 & 400.4 & 131.6 & 395.2 & 140.5 & 1352.4 \\
\hline CG9 & Jul. 2007 & 9 & 100 & $68-92$ & 13.9 & 7.10 & 2260 & 265.7 & 36.8 & 85.6 & 2.3 & 290.7 & 133.3 & 521.3 & 220.8 & 1446.0 \\
\hline CG1 & Aug. 2010 & 10 & 100 & $71-93$ & 18.2 & 7.15 & 2280 & 212.5 & 72.3 & 184.0 & 3.5 & 561.0 & 201.4 & 282.6 & 282.8 & 1658.7 \\
\hline CG2 & Aug. 2010 & 14 & 120 & $72-107$ & 16.0 & 6.49 & 2050 & 187.7 & 48.5 & 106.0 & 2.3 & 288.4 & 189.2 & 263.9 & 199.4 & 1185.7 \\
\hline CG7 & Aug. 2010 & 14 & 92 & $59-88$ & 17.0 & 6.56 & 1761 & 198.5 & 51.1 & 97.8 & 1.0 & 892.9 & 240.5 & 334.7 & 145.9 & 1889.5 \\
\hline CG10 & Aug. 2010 & 5 & 90 & $59-86$ & 21.5 & 7.35 & 1586 & 207.7 & 42.4 & 62.0 & 26.4 & 923.5 & 306.9 & 295.7 & 205.4 & 1967.3 \\
\hline CG12 & Aug. 2010 & 36 & 100 & $68-93$ & 20.0 & 7.34 & 1362 & 183.0 & 31.9 & 81.3 & 1.6 & 380.8 & 146.2 & 90.1 & 318.5 & 1074.2 \\
\hline CG17 & Aug. 2010 & 15 & 110 & $68-97$ & 14.2 & 6.95 & 1370 & 149.1 & 38.3 & 82.9 & 1.5 & 343.4 & 134.1 & 278.8 & 163.7 & 1109.9 \\
\hline CG19 & Aug. 2010 & 12 & 62 & $43-59$ & 14.5 & 6.72 & 1481 & 220.0 & 72.1 & 70.6 & 2.0 & 390.0 & 219.1 & 265.6 & 446.5 & 1462.6 \\
\hline \multicolumn{17}{|c|}{ Fresh groundwater from the Quaternary aquifers: } \\
\hline QG3 & Nov. 2005 & 92 & 8.4 & $6-7.5$ & 12.5 & 7.75 & 636 & 98.8 & 15.8 & 22.0 & 2.5 & 43.6 & 54.8 & 63.8 & 198.3 & 400.4 \\
\hline QG4 & Nov. 2005 & 103 & 14 & $7-13$ & 15.5 & 8.04 & 1024 & 134.4 & 38.2 & 38.0 & 5.4 & 70.8 & 90.1 & 116.8 & 302.3 & 644.9 \\
\hline QG1 & Jun. 2006 & 14 & 17 & $9-16$ & 13.5 & 7.16 & 1555 & 206.8 & 67.9 & 138.4 & 1.4 & 202.9 & 130.5 & 45.2 & 371.3 & 978.7 \\
\hline QG3 & Jun. 2006 & 92 & 8.4 & $6-7.5$ & 12.8 & 7.49 & 618 & 67.5 & 12.8 & 18.9 & 2.9 & 39.7 & 61.6 & 51.7 & 123.0 & 316.6 \\
\hline QG4 & Jun. 2006 & 103 & 14 & $7-13$ & 13.2 & 7.38 & 781 & 125.2 & 33.4 & 42.9 & 11.4 & 61.8 & 68.6 & 81.7 & 304.0 & 577.1 \\
\hline QG3 & Jul. 2007 & 92 & 8.4 & $6-7.5$ & 13.3 & 7.37 & 649 & 82.7 & 14.3 & 20.0 & 3.5 & 48.1 & 72.2 & 64.3 & 180.6 & 395.3 \\
\hline QG4 & Jul. 2007 & 103 & 14 & $7-13$ & 12.8 & 7.26 & 844 & 87.2 & 21.8 & 23.7 & 5.9 & 65.0 & 80.8 & 107.2 & 166.3 & 474.7 \\
\hline QG9 & Jul. 2007 & 13 & 20 & $12-17$ & 13.1 & 6.90 & 1298 & 109.3 & 29.7 & 93.5 & 0.2 & 152.9 & 119.9 & 238.2 & 174.9 & 831.0 \\
\hline QG13 & Jul. 2007 & 12 & 11 & 6-10 & 12.8 & 7.15 & 1267 & 134.8 & 15.2 & 40.4 & 0.0 & 122.1 & 94.0 & 223.7 & 200.7 & 730.6 \\
\hline QG3 & Aug. 2010 & 92 & 8.4 & $6-7.5$ & 18.3 & 6.96 & 821 & 118.3 & 21.6 & 28.6 & 4.0 & 103.3 & 135.4 & 74.7 & 190.5 & 581.2 \\
\hline QG4 & Aug. 2010 & 103 & 14 & 7-13 & 23.0 & 7.47 & 912 & 99.1 & 40.0 & 42.5 & 13.1 & 203.3 & 145.2 & 80.2 & 241.1 & 744.0 \\
\hline QG7 & Aug. 2010 & 14 & 28 & $15-24$ & 13.1 & 7.60 & 1242 & 156.2 & 27.5 & 82.1 & 1.0 & 254.5 & 54.4 & 146.6 & 262.0 & 853.4 \\
\hline \multicolumn{17}{|c|}{ Brackish groundwater from the Quaternary aquifers: } \\
\hline QG5 & Nov. 2005 & 12 & 12 & $7-11$ & 14.1 & 7.45 & 2360 & 275.6 & 55.3 & 184.3 & 0.9 & 292.2 & 95.2 & 280.3 & 206.1 & 1286.8 \\
\hline QG6 & Nov. 2005 & 2 & 14 & $8-13$ & 13.0 & 7.78 & 2740 & 158.3 & 77.9 & 316.5 & 4.8 & 491.6 & 108.1 & 33.8 & 296.8 & 1339.4 \\
\hline QG2 & Jun. 2006 & 12 & 22 & $15-21$ & 15.2 & 6.99 & 2310 & 244.9 & 66.3 & 198.5 & 3.6 & 315.7 & 134.2 & 386.3 & 512.7 & 1605.7 \\
\hline QG5 & Jun. 2006 & 12 & 12 & 7-11 & 12.4 & 7.02 & 2150 & 270.4 & 67.5 & 286.6 & 0.6 & 330.1 & 135.1 & 324.9 & 362.4 & 1596.3 \\
\hline QG11 & Jun. 2006 & 5 & 17 & 8-15 & 13.9 & 7.18 & 2820 & 153.8 & 69.2 & 229.2 & 4.4 & 448.3 & 207.6 & 190.6 & 200.9 & 1403.4 \\
\hline QG2 & Jul. 2007 & 12 & 22 & $15-21$ & 15.1 & 6.58 & 2260 & 208.4 & 52.6 & 131.3 & 2.2 & 369.8 & 140.4 & 517.2 & 63.1 & 1453.5 \\
\hline QG5 & Jul. 2007 & 12 & 12 & $7-11$ & 13.8 & 7.00 & 2050 & 137.5 & 30.1 & 124.5 & 0.8 & 320.9 & 116.9 & 355.0 & 177.8 & 1174.7 \\
\hline QG10 & Jul. 2007 & 3 & 10 & $6-9$ & 13.1 & 7.06 & 2900 & 84.2 & 37.5 & 185.5 & 2.7 & 672.3 & 198.8 & 127.8 & 316.8 & 1467.3 \\
\hline QG11 & Jul. 2007 & 5 & 17 & $8-15$ & 14.0 & 6.98 & 2950 & 132.8 & 43.2 & 158.1 & 4.4 & 593.7 & 263.0 & 259.0 & 278.1 & 1593.3 \\
\hline QG5 & Aug. 2010 & 12 & 12 & $7-11$ & 17.1 & 7.01 & 1903 & 208.4 & 44.7 & 146.0 & 0.5 & 281.3 & 254.3 & 337.3 & 199.4 & 1372.2 \\
\hline QG8 & Aug. 2010 & 2 & 15 & $9-14$ & 16.4 & 7.44 & 1633 & 154.6 & 47.5 & 134.5 & 2.7 & 269.8 & 285.9 & 256.9 & 220.3 & 1262.0 \\
\hline QG9 & Aug. 2010 & 13 & 20 & $12-17$ & 20.7 & 7.29 & 1289 & 151.4 & 49.1 & 67.8 & 7.6 & 299.4 & 216.2 & 133.5 & 241.1 & 1045.6 \\
\hline QG10 & Aug. 2010 & 3 & 10 & $6-9$ & 13.9 & 7.16 & 2210 & 128.2 & 51.0 & 286.1 & 12.8 & 640.6 & 211.5 & 156.1 & 309.6 & 1641.1 \\
\hline QG11 & Aug. 2010 & 5 & 17 & $8-15$ & 23.2 & 7.44 & 2780 & 205.8 & 74.8 & 295.5 & 11.1 & 469.4 & 344.9 & 259.5 & 291.7 & 1806.8 \\
\hline QG12 & Aug. 2010 & 14 & 17 & $12-16$ & 14.2 & 7.02 & 2210 & 274.7 & 49.6 & 154.6 & 2.3 & 386.2 & 368.8 & 347.9 & 300.7 & 1734.4 \\
\hline Seawater & from Bohai S & & & & & & & & & & & & & & & \\
\hline SW4 & Nov. 2005 & & & & 15.0 & 8.63 & 49,100 & 500.9 & 1409.6 & 9635.2 & 229.0 & $19,137.2$ & 2248.0 & 237.9 & 135.0 & $33,465.3$ \\
\hline sw2 & Jul. 2007 & & & & 25.0 & 7.81 & 48,100 & 146.8 & 645.3 & 5827.2 & 182.6 & $19,089.6$ & 2648.8 & 47.1 & 149.1 & $28,661.9$ \\
\hline SW1 & Aug. 2010 & & & & 26.8 & 7.65 & 43,800 & 324.5 & 978.8 & 7626.0 & 289.1 & $16,683.9$ & 4116.0 & 1092.0 & 163.7 & $31,192.2$ \\
\hline
\end{tabular}


the method of Plummer and Busenberg (1999). The instrument was calibrated to standards at the beginning and ending of each day keeping the test stable, with the error less than $2 \%$ for CFC- 11 and CFC-12, and $5 \%$ for CFC-113. CFC apparent ages of water samples can be calculated using the method of Plummer et al. (2006), assuming a recharge temperature of $13^{\circ} \mathrm{C}$ (mean air temperature) and a recharge elevation of 100 m.a.s.l. Although apparent ages represent ideal conditions with no mixing, they provide a good first approximation for groundwater age. The analyzed results are reported on the calibration scale (Prinn et al., 2000) and shown in Table 2.

3.3. Tritium $\left({ }^{3} \mathrm{H}\right)$ contents analysis and mean residence time (MRT) estimation

Tritium contents of 42 water samples (including 41 groundwater samples and 1 seawater sample) were determined on electrolytically enriched water samples by low-level proportional counting (Eichinger et al., 1980) at the Institute of Hydrogeology and Environmental Geology, Chinese Academy of Geological Sciences. The results are reported in tritium units (TU), with an error of $\pm 0.5 \sim 1.2$ TU. The tested results are shown in Table 2.

Lumped parameter models (LPMs) have been effectively used for estimating groundwater MRT in many natural systems, particularly in karst aquifers (Mangin, 1994; Zuber et al., 2004; Olsthoorn, 2008;
Long and Putnam, 2009). Although these models are simple and represent ideal systems, they require less data than more complex methods. Three LPMs were chosen for each aquifer. For the COA, The exponential mixing model (EPM), the binary exponential piston model (BEP) and a two compartment dispersion model with binary mixing (BDD) were implemented. For the QA, both the BEP and the BDD models were also used in addition to the dispersion model (DM). Each of these models is based on an idealized representation of groundwater flow and age. By using multiple models, we can capture the possible ranges of age distributions at the site. The applicability of these models is discussed in Section 5.3.2. The TracerLPM (version 1) workbook (Jurgens et al., 2012), available from U.S. Geological Survey can be used for estimating groundwater age distributions using tritium data. TracerLPM provides solutions for the convolution integral for each of the LPMs used in this study.

\section{Results}

\subsection{Chemical composition of groundwaters}

The results of the hydrochemical analyses of the water samples from the coastal aquifer can be seen in Table 1 . The groundwater from the karstified COA is characterized by a wide range of EC values (749-3340 $\mu \mathrm{s} / \mathrm{cm}$ ), temperatures ranging from 12.6 to $22.0^{\circ} \mathrm{C}$ and $\mathrm{pH}$

Table 2

Stable isotopes composition, tritium $\left({ }^{3} \mathrm{H}\right)$, and CFC concentrations in water samples.

\begin{tabular}{|c|c|c|c|c|c|c|c|c|c|c|c|}
\hline Sample & $\begin{array}{l}\text { Sampling } \\
\text { time }\end{array}$ & $\begin{array}{l}\text { WellDepth } \\
(\mathrm{m})\end{array}$ & $\begin{array}{l}\text { Screen interval } \\
(\mathrm{m})\end{array}$ & $\begin{array}{l}\delta^{18} \mathrm{O} \\
(\% \circ)\end{array}$ & $\begin{array}{l}\delta^{2} \mathrm{H} \\
(\%)\end{array}$ & $\begin{array}{l}{ }^{3} \mathrm{H} \\
(\mathrm{TU})\end{array}$ & $\begin{array}{l}\sigma \\
(\mathrm{TU})\end{array}$ & $\begin{array}{l}\text { CFC-11 } \\
\text { (pptv) }\end{array}$ & $\begin{array}{l}\text { CFC-12 } \\
\text { (pptv) }\end{array}$ & $\begin{array}{l}\text { CFC-113 } \\
\text { (pptv) }\end{array}$ & $\begin{array}{l}\text { CFC-12 } \\
\text { apparent age (a) }\end{array}$ \\
\hline CG1 & Nov. 2005 & 100 & $71-93$ & -7.2 & -57 & 8.4 & 0.7 & pptv & & & \\
\hline CG1 & Jun. 2006 & 100 & $71-93$ & -7.8 & -57 & 7.6 & 0.7 & 242 & 269 & 43 & 29 \\
\hline CG1 & Jul. 2007 & 100 & $71-93$ & -6.8 & -53 & 13.4 & 1.4 & 14 & 345 & 45 & 25 \\
\hline CG1 & Aug. 2010 & 100 & 71-93 & -7.9 & -57 & 11.4 & 1.2 & & & & \\
\hline CG2 & Nov. 2005 & 120 & $72-107$ & -7.2 & -59 & 8 & 0.6 & & & & \\
\hline CG2 & Jun. 2006 & 120 & $72-107$ & -8.5 & -57 & 5.3 & 0.7 & C & 545 & 73 & 7 \\
\hline CG2 & Jul. 2007 & 120 & $72-107$ & -7.2 & -55 & 9.6 & 1.0 & $\mathrm{C}$ & C & C & \\
\hline CG2 & Aug. 2010 & 120 & $72-107$ & -8.2 & -59 & 8.8 & 1.2 & & & & \\
\hline CG3 & Nov. 2005 & 110 & $72-98$ & -7.1 & -62 & 2.8 & 0.6 & & & & \\
\hline CG3 & Jun. 2006 & 110 & $72-98$ & -7.4 & -57 & 5 & 0.6 & $\mathrm{C}$ & 377 & 67 & 22.5 \\
\hline CG3 & Jul. 2007 & 110 & $72-98$ & -8.3 & -57 & 9.2 & 1.2 & 20 & 433 & 67 & 20.5 \\
\hline CG3 & Aug. 2010 & 110 & $72-98$ & -8.4 & -57 & 9.6 & 1.2 & & & & \\
\hline CG4 & Nov. 2005 & 100 & $70-95$ & -7.6 & -61 & 5.7 & 0.6 & & & & \\
\hline CG4 & Jul. 2007 & 120 & $70-95$ & -7.2 & -56 & 10.3 & 1.1 & 50 & 390 & 163 & 22.5 \\
\hline CG4 & Aug. 2010 & 100 & $70-95$ & -8.2 & -59 & 8.9 & 1.3 & & & & \\
\hline CG5 & Nov. 2005 & 120 & $75-112$ & -6.9 & -60 & 7.2 & 0.7 & & & & \\
\hline CG7 & Aug. 2010 & 92 & $59-88$ & -8.1 & -58 & 11.4 & 1.2 & & & & \\
\hline CG20 & Nov. 2005 & 105 & $76-101$ & -7.0 & -51 & 2.7 & 0.6 & & & & \\
\hline CG12 & Jul. 2007 & 100 & $68-93$ & -8.0 & -59 & 10.1 & 1.1 & & & & \\
\hline CG12 & Aug. 2010 & 100 & $68-93$ & -8.3 & -59 & 15.3 & 1.3 & & & & \\
\hline CG9 & Aug. 2010 & 100 & $68-92$ & -10.0 & -65 & 7 & 0.9 & & & & \\
\hline CG19 & Aug. 2010 & 62 & $43-59$ & -8.3 & -57 & 9.7 & 1.0 & & & & \\
\hline CG10 & Aug. 2010 & 90 & $59-86$ & -8.0 & -57 & 9.2 & 1.0 & & & & \\
\hline QG2 & Jun. 2006 & 22 & $15-21$ & -8.8 & -58 & 7.5 & 0.5 & 114 & 403 & 50 & 21 \\
\hline QG2 & Jul. 2007 & 22 & $15-21$ & -7.2 & -54 & 12.3 & 1.2 & 20 & 429 & 66 & 20.5 \\
\hline QG3 & Nov. 2005 & 8.4 & $6-7.5$ & -7.4 & -62 & 5.6 & 0.6 & & & & \\
\hline QG3 & Jun. 2006 & 8.4 & $6-7.5$ & -9.1 & -58 & 5 & 0.6 & & & & \\
\hline QG3 & Aug. 2010 & 8.4 & $6-7.5$ & -8.2 & -56 & 3.4 & 1.5 & & & & \\
\hline QG4 & Nov. 2005 & 14 & $7-13$ & -8.2 & -58 & 5.7 & 0.6 & & & & \\
\hline QG4 & Jun. 2006 & 14 & $7-13$ & -7.5 & -59 & 5.6 & 0.6 & & & & \\
\hline QG5 & Nov. 2005 & 12 & $7-11$ & -7.3 & -57 & 7.4 & 0.6 & & & & \\
\hline QG5 & Aug. 2010 & 12 & $7-11$ & -8.1 & -57 & 9.2 & 1.0 & & & & \\
\hline QG6 & Nov. 2005 & 14 & 8-13 & -6.9 & -57 & 9.4 & 0.7 & & & & \\
\hline QG7 & Aug. 2010 & 28 & $15-24$ & -7.3 & -52 & 11.8 & 1.2 & & & & \\
\hline QG11 & Jun. 2006 & 17 & $8-15$ & -7.8 & -58 & 7 & 0.5 & $C$ & 342 & 45 & 24.5 \\
\hline QG11 & Jul. 2007 & 17 & $8-15$ & -7.0 & -55 & 9.9 & 1.1 & 13 & 345 & 41 & 25 \\
\hline QG11 & Aug. 2010 & 17 & $8-15$ & -7.8 & -57 & 9 & 1.0 & & & & \\
\hline QG8 & Aug. 2010 & 15 & $9-14$ & -8.4 & -57 & 11.6 & 1.2 & & & & \\
\hline QG9 & Aug. 2010 & 20 & $12-17$ & -8.2 & -59 & 9.7 & 1.1 & & & & \\
\hline QG10 & Aug. 2010 & 10 & $6-9$ & -7.9 & -56 & 9.9 & 1.1 & & & & \\
\hline QG12 & Aug. 2010 & 17 & $12-16$ & -8.2 & -57 & 11.8 & 1.2 & & & & \\
\hline Seawater & Nov. 2005 & & & -0.5 & -17 & 3.8 & 0.6 & & & & \\
\hline
\end{tabular}

$\mathrm{C}$ - the CFC concentration exceeds that for solubility equilibrium with modern air. 
values between 6.4 and 7.9. The groundwater from the QA shows the similar ranges for EC (618-2950 $\mu \mathrm{s} / \mathrm{cm})$, with water temperatures ranging from 12.4 to $23.2^{\circ} \mathrm{C}$, and $\mathrm{pH}$ values from 6.6 to 8.0. The local seawater has high EC values (43,800-49,100 $\mu \mathrm{s} / \mathrm{cm})$. The water types change from $\mathrm{Ca}(\cdot \mathrm{Mg})-\mathrm{HCO}_{3} \cdot \mathrm{Cl}$ type to $\mathrm{Ca}(\cdot \mathrm{Na})-\mathrm{Cl}\left(\cdot \mathrm{HCO}_{3}\right)$ type to $\mathrm{Na} \cdot \mathrm{Ca}-\mathrm{Cl}$ type, from the east towards the sea.

The plots of major ions/Cl ratios vs TDS (Fig. 4) show that only a small number of samples are located along or close to the mixing line between seawater and freshwater. With increasing TDS, the points of most groundwater samples in Fig. 4 have a pronounced excursion away from the mixing line and are scattered with a decreasing trend. Based on the method of Appelo and Postma (2005), depletion or enrichment of major cations (Fig. 5) can be calculated by comparing the theoretical concentration and the measured concentration. Most of groundwater displays significant $\mathrm{Na}^{+}$deficiencies (Na-react) compared to a pure mixing model, with a maximum depletion of $20 \mathrm{meq} / \mathrm{L}$ for the groundwater sample collected from CG10.

Nitrate concentrations in the investigated groundwaters range from 32.6 to $521.3 \mathrm{mg} / \mathrm{L}$ with a mean value of $191.2 \mathrm{mg} / \mathrm{L}$. These values seriously exceed the safe drinking water guidelines $(20 \mathrm{mg} / \mathrm{L})$ in China. The higher concentrations of $\mathrm{NO}_{3}^{-}$mainly occur in the brackish groundwater collected from the western part of the Daweijia well field (Fig. 6). The groundwater from the QA and the COA have similar ranges (33.8$517.2 \mathrm{mg} / \mathrm{L}$ and $32.6-521.3 \mathrm{mg} / \mathrm{L}$, respectively) and average values (194.8 mg/L and $183.8 \mathrm{mg} / \mathrm{L}$, respectively) of $\mathrm{NO}_{3}^{-}$concentrations. Compared with the average $\mathrm{NO}_{3}^{-}$concentrations measured for groundwater in the QA and COA in 1962 of $9.9 \mathrm{mg} / \mathrm{L}$ and $10.9 \mathrm{mg} / \mathrm{L}$, respectively (Lü et al., 1981), the current $\mathrm{NO}_{3}^{-}$concentrations are significantly elevated. The anthropogenic pollution to the groundwater environment has become increasingly serious in the past decades.

\subsection{Stable isotopes $\left(\delta^{18} \mathrm{O}-\delta^{2} \mathrm{H}\right)$}

The $\delta^{18} \mathrm{O}$ and $\delta^{2} \mathrm{H}$ values of the sixty-eight groundwater samples (Table 2) plot mostly to the lower right of the Global Meteoric Water Line (GMWL: $\delta^{2} \mathrm{H}=8 \delta^{18} \mathrm{O}+10$; Craig, 1961), and close to the local
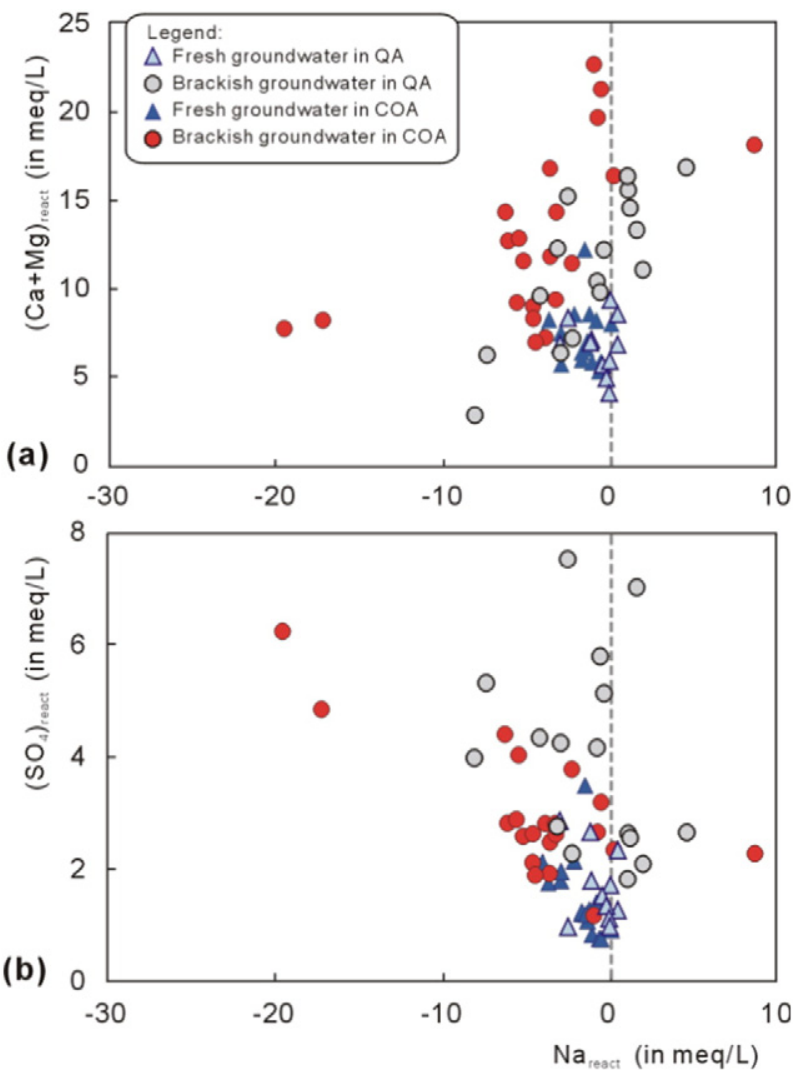

Fig. 5. $\mathrm{Na}_{\text {react }}$ Vs. (a) $(\mathrm{Ca}+\mathrm{Mg})_{\text {react }}$ and (b) $\mathrm{SO}_{4 \text { react }}$ for the collected groundwater samples.

meteoric water line (LMWL). The LMWL, which can be represented as $\delta^{2} \mathrm{H}=7.7 \delta^{18} \mathrm{O}+8.7$ (Zhang et al., 1991) (Fig. 2), was obtained using $\delta^{18} \mathrm{O}$ and $\delta^{2} \mathrm{H}$ values of average monthly rainfall (IAEA/WMO/GNIP) monitored at Yantai station $\left(39^{\circ} 05^{\prime} 09^{\prime \prime} \mathrm{N}, 117^{\circ} 11^{\prime} 47^{\prime \prime} \mathrm{E}\right)$ some $187 \mathrm{~km}$
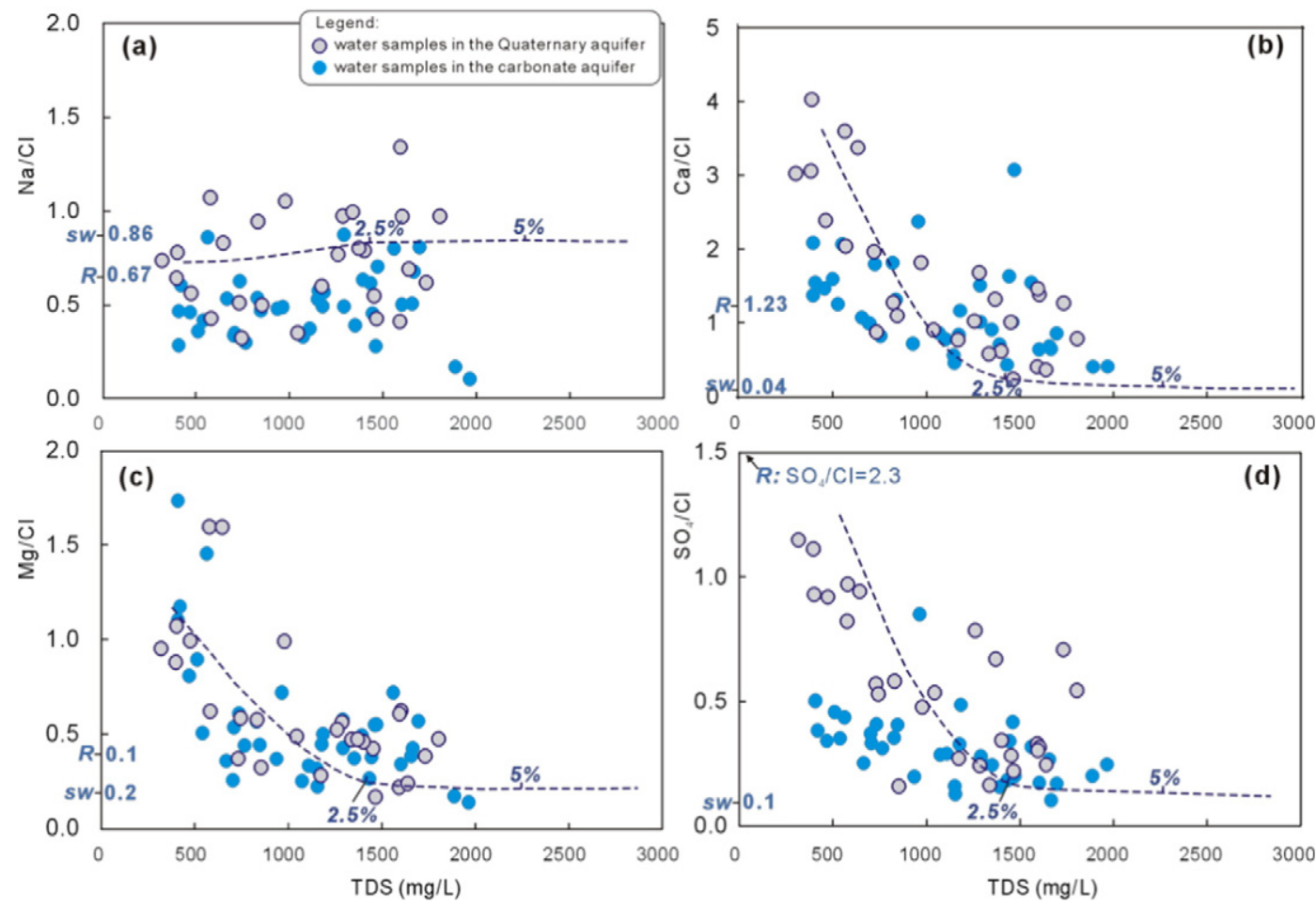

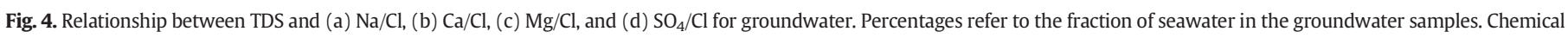
compositions in rainwater (R) are from Zhang et al. (2012), and seawater data (sw) are from Clark and Fritz (1997). 
SW of study area. The groundwater samples have $\delta^{18} \mathrm{O}$ values ranging from -10.3 to $-5.1 \%$ and $\delta^{2} \mathrm{H}$ values ranging from -65 to $-51 \%$, with mean values of $-7.7 \%$ and $-57 \%$ respectively. Most of the water samples collected in the relatively dry season (November 2005 and June 2006) show $\delta^{2} \mathrm{H}$ depletion relative to that of waters sampled in the wet season (July 2007 and August 2010) (Fig. 7a). The local seawater is weakly depleted in $\delta^{18} \mathrm{O}$ values $(-1.9 \sim-0.8 \%$ ) relative to the modern ocean waters (0\%, Clark and Fritz, 1997). As shown in the insert diagram in Fig. 7a, there is no obvious mixing trend between seawater and fresh groundwater. There is a relatively wider range of $\delta^{18} \mathrm{O}$ values for the groundwater samples collected from the COA (Fig. 8). In the recharge area, fresh groundwater from the QA is slightly heavy in $\delta^{18} \mathrm{O}$ values with a median value of $-7.5 \%$, compared with median value of $-8.1 \%$ in the deep brackish groundwater of the COA. The groundwater investigated in this study displays a narrow range of $\delta^{18} \mathrm{O}$ compositions.

\subsection{Chlorofluorocarbons (CFCS) and tritium contents in the groundwater}

Eleven groundwater samples collected from the study area were analyzed for CFC concentrations, including CFC-11 (12.5-242.1 pptv), CFC12 (269.1-544.6 pptv) and CFC-113 (41.2-162.8 pptv) under the airwater balance at the determined recharge temperatures. Results could not be obtained for one sample (CG2 collected in July 2007) due to concentrations exceeding equilibrium with air.

The tritium concentrations of 41 groundwater samples have a wide range, with values between 2.7 and $15.3 \mathrm{TU}$ (Table 2) and a mean value of $8.5 \mathrm{TU}$. In comparison to the tritium contents (2.7-11.8 TU with mean $7.2 \mathrm{TU}$ ) of fresh groundwater, there is a relatively wide range (2.8-15.3 TU, with mean 9.2 TU) of tritium contents in brackish groundwater. 2006 was a relatively dry year, and sampling was undertaken prior to the wet season. Generally, groundwater collected in the wet season (Jul. 2007 and Aug. 2010) has higher tritium contents (3.4-15.3 TU with mean $10.1 \mathrm{TU}$ ) than water samples collected in the dry season (2.7-9.4 TU, with mean 6.2 TU, Nov. 2005 and Jun. 2006). This suggests a fast groundwater response to the rainfall in the coastal aquifers. The distribution of tritium concentrations varies with distance from the coast (Fig. 9). Tritium concentrations show an increasing trend from the recharge area towards the coastal area. The groundwater is mainly recharged by the infiltration of precipitation and mountain front lateral flow in the aquifers of the Daweijia area.

\section{Discussion}

\subsection{Groundwater flow system}

Stable isotopic compositions $\left(\delta^{18} \mathrm{O}\right.$ and $\left.\delta^{2} \mathrm{H}\right)$ are useful for determining the origin and movement of groundwater as they are generally modified by meteoric processes only and are not changed readily as a result of water-rock interactions at low temperatures (e.g., Sidle, 1998). The scatter points of $\delta^{18} \mathrm{O}-\delta^{2} \mathrm{H}$ values of most groundwater samples from the COA and QA are close to the LMWL, suggesting rapid recharge of the groundwater aquifers by local precipitation. The fresh groundwater from the COA has a relatively wider range of isotopic compositions, for both $\delta^{18} \mathrm{O}$ and $\delta^{2} \mathrm{H}$ values, reflecting that groundwater flow dynamics are relatively complex due to the existence of dual porosity in the karst system.

The $\delta^{18} \mathrm{O}-\delta^{2} \mathrm{H}$ relationship for the groundwater samples can be defined by the following linear regression equations: $\delta^{2} \mathrm{H}=0.73 \delta^{18} \mathrm{O}$ -52.2 for the dry season (November 2005, June 2006) and $\delta^{2} \mathrm{H}=2.66$ $\delta^{18} \mathrm{O}-35.7$ for wet season (July 2007, August 2010). The lower slope of these equations relative to that of the LMWL (slope $=7.7$ ) in the study area suggests evaporation is likely to be occurring prior to recharge of the aquifers. It is noted that the d-excess (d-excess $=\delta^{2} \mathrm{H}$ $8 \delta^{18} \mathrm{O}$ defined by Dansgaard, 1964) of most groundwater samples collected in the dry season is lower than that of the rest of the groundwater samples collected in the wet season. The relatively higher $d$-excess values in some groundwater samples (e.g., CG8, CG9) collected in summer (values higher than 10, the y-intercept of the GMWL) may be contributed by secondary evaporative processes locally prior to recharge. In contrast, these samples were collected from greater depths (90-100) and still have a higher concentration of nitrate $(148-521 \mathrm{mg} / \mathrm{L})$, indicating relatively rapid incorporation of recycled precipitation and irrigation return flow. This has also been confirmed by using fluid electric logging method (Wu and Jin, 1990).

Some shallow brackish groundwater from the QA displays a similar isotopic composition with groundwater from the COA suggesting good connection between the two aquifers. Brackish groundwater observed at some locations close to the SE fault (F1) has become fresh in recent years (e.g., CG3, CG5 and CG9). However, no obvious alteration is observed in the isotopic compositions. Around the Daweijia well field, the deeper groundwater from the COA is mainly characterized by $\mathrm{Ca}-\mathrm{Cl}$ type water with narrow $\delta^{18} \mathrm{O}$ values ranging from -8.1 to $-7.0 \%$. $\mathrm{NO}_{3}^{-}$concentrations of groundwater samples in some wells (e.g., CG7, CG2 and CG17) are high (ranging from 263.9 to $334.7 \mathrm{mg} / \mathrm{L}$ in Aug 2010). However, $\mathrm{NO}_{3}^{-}$concentrations obtained from $\mathrm{CG} 3$ are relatively low (ranging from 32.6 to 79.6 in the monitoring periods). This suggests that the wells CG7, CG2 and CG17 might be connected along permeable conduits, which has been also observed by using fluid electric logging method (Wu and Jin, 1990). For the shallow groundwater samples near the Daweijia well field (e.g., QG2, QG5, QG7, and QG9), higher $\delta^{18} \mathrm{O}$ values may have resulted from the recycling of irrigation return flows. These wells also have higher $\mathrm{NO}_{3}^{-}$concentrations ( $255-517 \mathrm{mg} / \mathrm{L}$ ), indicating that apart from CG3, other investigated deeper groundwater is affected by the vertical flow to great extent.

\subsection{Origin of groundwater salinity and anthropogenic input}

The relationships between major ions/Cl ratios and TDS (Fig. 4) in groundwater samples indicate that other sources besides rainwater infiltration and seawater intrusion can be responsible for modifying the chemical compositions of groundwater. The enrichments of $\mathrm{Ca}^{2+}$ and $\mathrm{SO}_{4}^{2-}$ (Fig. 5a and b) suggest that strong water-rock interaction (e.g. cation-exchange reactions between groundwater and the clay-rich materials of the aquifer, dissolution/precipitation of carbonate minerals) and anthropogenic input might take place in the aquifers. If we assumed that $\mathrm{Cl}$ mainly originated from historical seawater intrusion without anthropogenic contribution, we can calculate the fraction of seawater to be less than $5 \%$ in the collected water samples. $\mathrm{Cl}$ can be also contributed by anthropogenic activities, hence the fraction of seawater is readily overestimated. The $\delta^{18} \mathrm{O}-\delta^{2} \mathrm{H}$ relationship (Fig. 7) and the graph of $\delta^{18} \mathrm{O}$ vs. $\mathrm{Cl}$ concentration (Fig. 10) do not show obvious mixing processes between seawater and freshwater in the aquifers. Currently, the mixing processes between fresh groundwater and seawater are very limited. When seawater intrudes into a freshwater coastal aquifer, a depletion of $\mathrm{Na}$ is associated with a cation exchange processes. Shifting hydrochemical composition towards the $\mathrm{Ca}-\mathrm{Cl}$ water type occurring in the deep groundwater (e.g., wells CG7 and CG10) from the COA indicates that seawater intrudes into this coastal fresh water aquifer. Just like the findings of Wu and Jin (1990), the potential flow path could be defined again from CG10 $\rightarrow$ CG1 $\rightarrow$ CG $\rightarrow$ CG7 with mixing between fresh groundwater and seawater of varying extent. Compared with the higher fraction (20\%) of seawater intrusion measured in 1982 during the intensive groundwater abstraction (Fan, 1984), the minor evidence of seawater intrusion currently indicates that the restrictive measures on groundwater abstraction have been effective in reducing the degree of seawater intrusion.

The nitrate $\left(\mathrm{NO}_{3}^{-}\right)$contamination measured in the collected groundwater samples varies over a wide range (32.6-521.3 mg/L, with mean $191.2 \mathrm{mg} / \mathrm{L}$ ). This is attributed to the extensive irrigation activities in the study area. The relationship between $\mathrm{NO}_{3}^{-}$concentration and the fraction of seawater (Fig. 11a) can be used to identify the $\mathrm{NO}_{3}^{-}$sources 


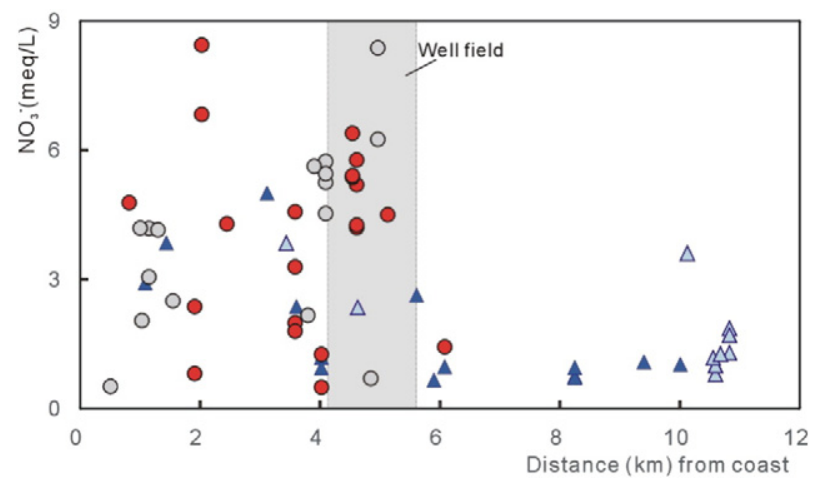

Fig. 6. Variation of $\mathrm{NO}_{3}^{-}$concentration in the groundwater with the distance from coast. See Fig. 5 for legend.

as either agricultural contamination or seawater intrusion. The offshore seawater displays higher $\mathrm{NO}_{3}^{-}$concentrations (up to $1092 \mathrm{mg} / \mathrm{L}$ in Aug. 2010). Near the coastal area, the $\mathrm{NO}_{3}^{-}$concentrations in the groundwater increase with the fraction of seawater, indicating seawater as the source. Near the Daweijia well field, groundwater with a lower fraction of seawater shows higher $\mathrm{NO}_{3}^{-}$concentrations, suggesting the contamination originates from using agricultural fertilizer in this part of the catchment. The plot of $\mathrm{NO}_{3}^{-} / \mathrm{Cl}^{-}$ratio vs. $\mathrm{Cl}^{-}$(Fig. $11 \mathrm{~b}$ ) shows that the ratios of brackish groundwater samples decline with an increase in $\mathrm{Cl}^{-}$concentrations. Most of the brackish groundwater presents lower $\mathrm{NO}_{3}^{-} / \mathrm{Cl}^{-}$ratios under the higher $\mathrm{Cl}^{-}$-bearing seawater intrusion into the fresh water aquifer. However, compared with the relatively lower $\mathrm{NO}_{3}^{-} / \mathrm{Cl}^{-}$ratio $(\sim 0.01)$ in the Bohai seawater, the increase in the $\mathrm{NO}_{3}^{-} /$ $\mathrm{Cl}^{-}$ratios of some fresh and brackish groundwater indicates a strong anthropogenic contamination, especially from excessive use of $\mathrm{Ca}\left(\mathrm{NO}_{3}\right)_{2}$-fertilizers. The similar $\mathrm{Cl}^{-}$concentrations and $\mathrm{NO}_{3}^{-} / \mathrm{Cl}^{-}$ratios in fresh and brackish groundwater from the QA and COA is consistent with other observations of aquifer connection and rapid infiltration.

\subsection{Groundwater mean residence times}

\subsubsection{Chlorofluorocarbons (CFCS) and groundwater apparent ages}

Concentrations of CFCs can be used to interpret groundwater age in the coastal aquifers based on historical data for atmospheric mixing ratios of these compounds over the past 60 years. The accuracy of this information will depend on the reliability of the concentration data (i.e. susceptibility to contamination, degradation and retardation) and the ability of the model of age frequency to represent the system. CFC-12 and CFC-113 concentrations in many water samples plot within regions bounded by piston flow and binary mixing of young and old water (Fig. 12A). Groundwater from location CG2 collected in June 2006 is somewhat elevated in CFC-12 relative to CFC-113 (Fig. 12A) indicating this is a relatively young sample (post-1990 recharge dates). The piston- flow line for CFC-113 turns over in water recharged after 1995. The sample that appears enriched in CFC-12 could result from mixtures of recent and somewhat older water. Only groundwater collected from CG3 in June 2006, which plots outside the region bounded by piston flow and binary mixing, has been affected by contamination or degradation processes (Fig. 12B). Using the method proposed by Plummer et al. (2006), the CFC-12 apparent age can be regarded as the recommended age due to less potential for contamination during sampling, lower solubility in water, and less bias due to hydrodynamic dispersion than the other CFCs (Plummer et al., 1993; Busenberg et al., 1993). Apparent ages (CFC-12) of 10 groundwater samples ranged from 7 to 29 years using CFCs data (Table 2). The 'young fraction' is the fraction of a water sample that contains a detectible CFCs and tritium concentration caused by the post-1950s recharge. According to the method described by Han et al. (2012), the fraction of young water can be estimated from the binary mixing model curves based on CFC- 113 and CFC- 12 concentrations in groundwater. The fraction of young water in the selected water samples from the COA ranges from 0.52 to 0.87 .

Tracer-tracer concentration plots have some advantages over plots comparing apparent ages and tracer ratios for reflecting more directly the measured quantities and potential mixtures (Plummer et al., 2006). Because atmospheric ${ }^{3} \mathrm{H}$ concentrations have been elevated for a long time, old water components can be identified by anomalously low ${ }^{3} \mathrm{H}$ values in comparison with CFC-12 (Fig. 12B). The relationship between ${ }^{3} \mathrm{H}$ and $\mathrm{CFC}-12$ (Fig. 7B) shows that most points plot below the piston-flow line. This suggests mixtures lie between piston-flow and binary mixing of modern (2000) and old (pre- ${ }^{3} \mathrm{H}$ and pre-CFC) water, particularly in wells with screened intervals greater than $20 \mathrm{~m}$. Strong evidence for mixing (of any type) is indicated by the absence of any samples retaining the decayed, initial ${ }^{3} \mathrm{H}$ activity from the midand late-1960s bomb peak (Fig. 12B). The low ${ }^{3} \mathrm{H}$ activities in water samples coincide with higher CFC concentrations (Fig. 12B). The intensive agricultural activities in this study area can explain this apparent incongruence (Horst et al., 2008). In this area, groundwater is extracted for irrigation, and some portion of the water is recycled. The CFC concentration in irrigation return flow can be increased through contacting the higher CFC content in the air. Thus, the extracted groundwater reinfiltrates with successive irrigation cycles and increases CFC concentration in aquifers. Tritium content in groundwater is not affected by return flow during the irrigation process. The apparent ages of groundwater estimated from CFC-12 concentrations range from 7 to 29 years with young water fractions from $0.52-0.93$ (CFC-113/CFC-12 ratio). These might be underestimated for young groundwater in this area. Shallow groundwater (i.e. QG2) near the well field indicated young apparent ages (CFC-12) with $>90 \%$ young water, indicating a fast and a direct connection to recharge zones, presumably irrigation return flows.
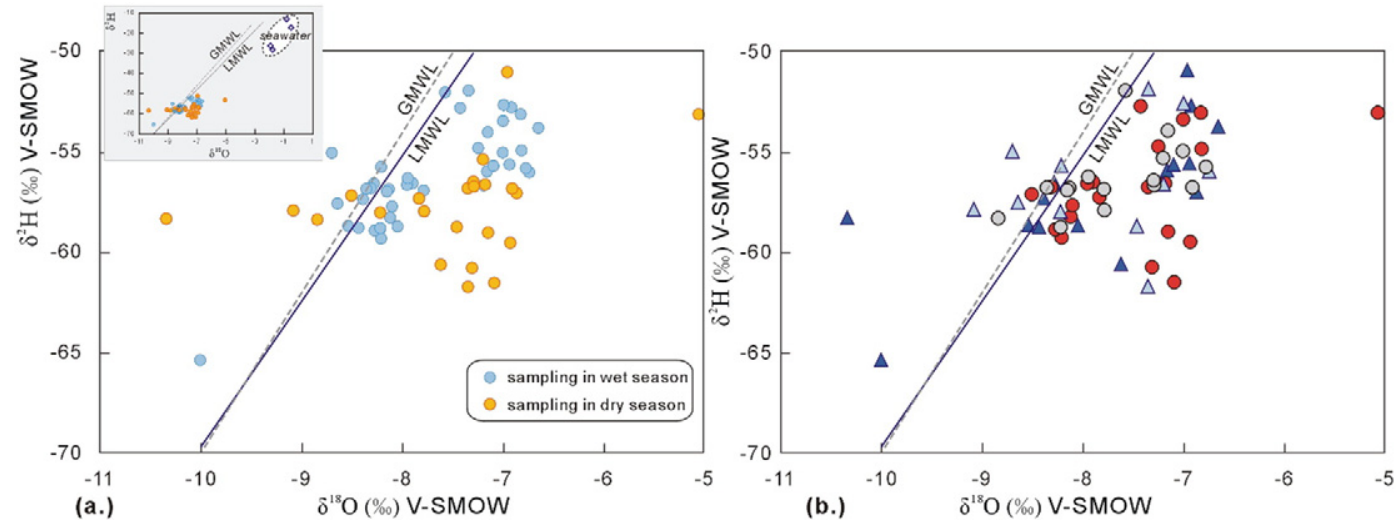

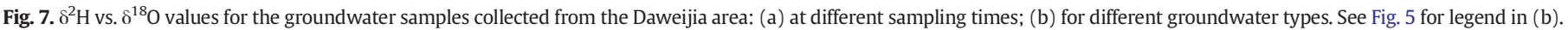




\subsubsection{Groundwater MRTs}

Tritium $\left({ }^{3} \mathrm{H}\right)$ is a naturally radioactive isotope of hydrogen $\left(\mathrm{t}_{1 / 2}=\right.$ $12.3 \mathrm{a})$ and is not affected significantly by reactions other than ratioactive decay. High tritium contents are observed in groundwater suggesting the presence of a fraction of the groundwater that is less than $\sim 50$ years old (Clark and Fritz, 1997). The tritium contents of groundwater in the west of the Daweijia well field showed wide variations (2.7-15.3 TU with mean value of 8.5 TU) (Fig. 4). This may be due to the contribution of complex hydrogeologic conditions with flow processes resulting in mixtures between water with high tritium contents (recently recharged water) and stored water with low tritium content.

The tritium age can be estimated by using lumped parameter models (LPM) (Maloszewski and Zuber, 1996; Zuber et al., 2001), which are an effective tool for analyzing karst groundwater systems (Mangin, 1994). Determining the input history for tritium is the key to calculating the groundwater age. Using the method discussed by IAEA (1992), the historical tritium concentrations in precipitation (Fig. 13) can be reconstructed from the available data in the International Atomic Energy Agency (IAEA) records. The reconstruction was undertaken using records from Shijiazhuang and Ottawa, Canada. The Shijiazhuang station can be regarded as a representative site for north China. The reconstructed tritium curve (1953-2008) shows similar fallout patterns throughout the Northern Hemisphere.

The conceptual model of the Daweijia area is very similar to that of Tampa, Florida (Eberts et al., 2012). Both aquifers are described as carbonate aquifers overlain by unconsolidated sediments. The LPMs applied to the carbonate aquifer of the Daweijia area included the EPM (the combined exponential and piston-flow model, Zuber et al., 2004), the BEP (BMM-EMM-PFM, a binary mixing model with an exponential mixing model and piston-flow model, Eberts et al., 2012) and the BDD (BMM-DM-DM, a binary mixing model with two-component dispersion model, Zuber et al., 2004) models. The inclusion of binary mixes is a convenient way to account for water older than the range of environmental tracers. The BDD model was thought to be potentially relevant because karst features can result in macro-dispersion. While the binary exponential piston flow model (BEP) also was considered to be conceptually feasible due to the hydrochemical evidence indicating that the production well produced a mixture of upper Quaternary groundwater and the deeper carbonate groundwater. Parameters for the BEP model are mean age of the mixture $\left(t_{\text {mean }}\right)$, mean age of the exponential component $\left(t_{\text {old }}\right)$, and age of the piston-flow component ( $\left.t_{\text {young }}\right)$. For the unconfined Quaternary aquifer, we applied the DM

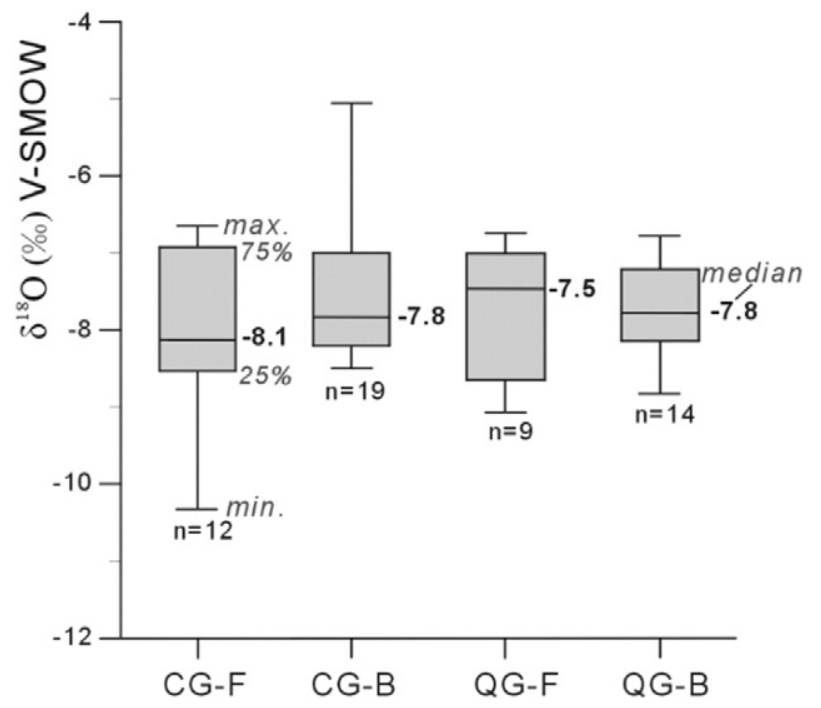

Fig. 8. Box diagrams showing variations of $\delta^{18} \mathrm{O}$ values for different groundwater types (CG-F fresh groundwater in the COA; CG-B brackish groundwater in the COA; QG-F fresh groundwater in the $\mathrm{QA}$; $\mathrm{QG}-\mathrm{B}$ brackish groundwater in the $\mathrm{QA}$ ).

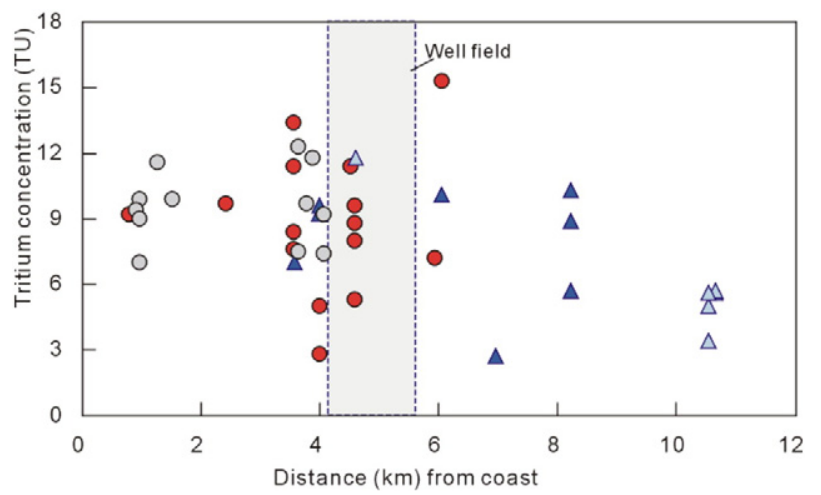

Fig. 9. Measured tritium concentrations of groundwater samples vs. distance from coast. See Fig. 5 for legend.

(dispersion model), the BEP and the BDD models. The relevant parameters and the model results were shown in Table 3. We assumed that the groundwater flow patterns are stable for different time periods in the carbonate aquifer system.

The simulated shapes of the age distributions from the different models can be seen for three selected wells (Fig. 14). Water from the well CG2 had a wide range of ages (Fig. 14a). The BEP model indicated a mean age of 163 years with a young water fraction (mean age 7 years) of approximately $28 \%$. The BDD model, which considers dispersive mixing along the flow path, reported a mean age older than that obtained from the BEP model. For the EPM model, the adjustment of the two parameters was unable to produce an acceptable match to the data, suggesting the model was unable to reflect the mixing conditions. Good fits are obtained with the EPM for the wells CG2 and CG3, with a MRT of roughly 100 years. Due to the complex porosity (conduits, fissures, matrix) existing in carbonate aquifer systems, the groundwater MRTs calibrated using observed ${ }^{3} \mathrm{H}$ data represent mixtures of water from conduits or fissures as well as stagnant water in the limestone matrix (Maloszewski and Zuber, 1996). Using the binary mixing model, the age of the old component was adjusted to best match the tritium data on the model curve. However it is hard to represent the tritium-free water, which could be of greater age than the model showed. Consequently, it is meaningful to discuss the mean age of the young component and its fraction in the water sample.

The lower tritium contents of the wells (e.g., CG3, QG3) can result in a relatively higher mean age of the young component (around 40 years). In contrast, well CG3 has lower $\mathrm{NO}_{3}$ concentrations and a mean age of the young component of 46 years using the BEP model (Fig. 14b). Although both of CG2 and CG3 are located around the Daweijia wellfield, these results suggest that there is no direct hydraulic connection between them.

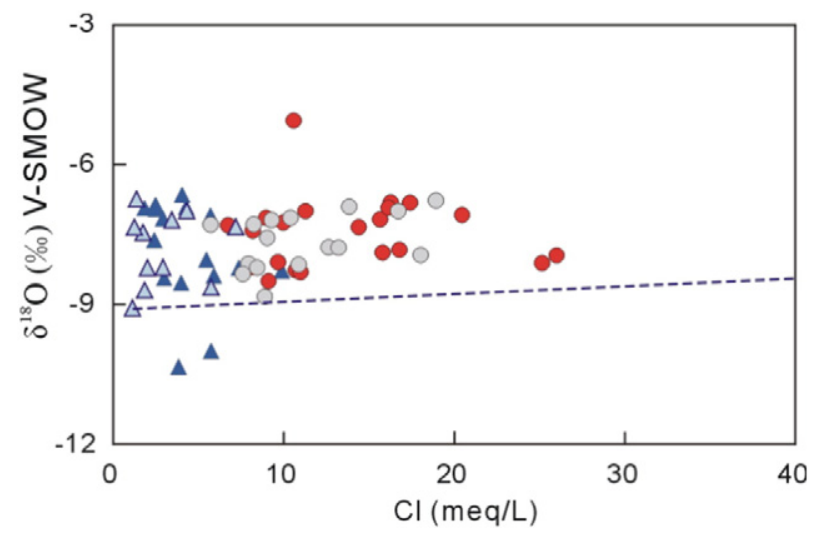

Fig. 10. Graph of $\delta^{18} \mathrm{O}$ vs. $\mathrm{Cl}$ concentration of groundwater samples. The dashed line refers to the conservative mixing line between fresh groundwater (QG3) and seawater. See Fig. 5 for legend. 

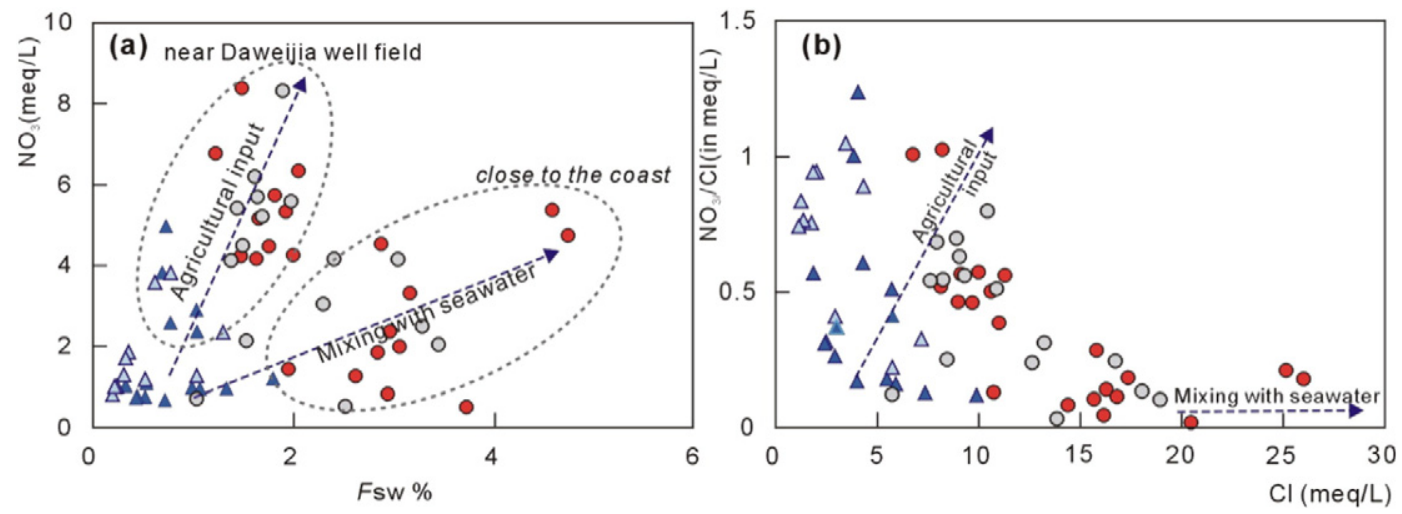

Fig. 11. (a) Relationship between $\mathrm{Fsw}$ and $\mathrm{NO}_{3}^{-}$concentration and (b) variations of $\mathrm{NO}_{3} / \mathrm{Cl}$ ratios with $\mathrm{Cl}$ concentrations of groundwater. See Fig. 5 for legend.

This has been confirmed by the hydrochemical data previously. Well CG4 located near the fault zone in the upstream area has a MRT of 95 years using the EPM. Alternatively, the mean age of the young component in CG4 is 4 years with $\beta=0.7$ using the BEP model, and 45 years with $\beta=0.65$ using the BDD model. CG4 is also a production well used mainly for local domestic supply. Low nitrate concentrations (46-61 mg/L), suggests that groundwater at this location has a relatively low contribution of recent waters. For the wells CG5 and CG 12 located in the southern hills (surface elevation $\sim 35 \mathrm{~m}$ ), the BEP model predicts a mean age of the young component of 6 years (Table 3 ). Using the both the BDD and the BEP model for groundwater collected from CG7 and CG10 suggests that the two-component flow models are poor representations of the groundwater age distribution at these locations. Even with mean age of the young component of 1 year, the models cannot explain the tritium

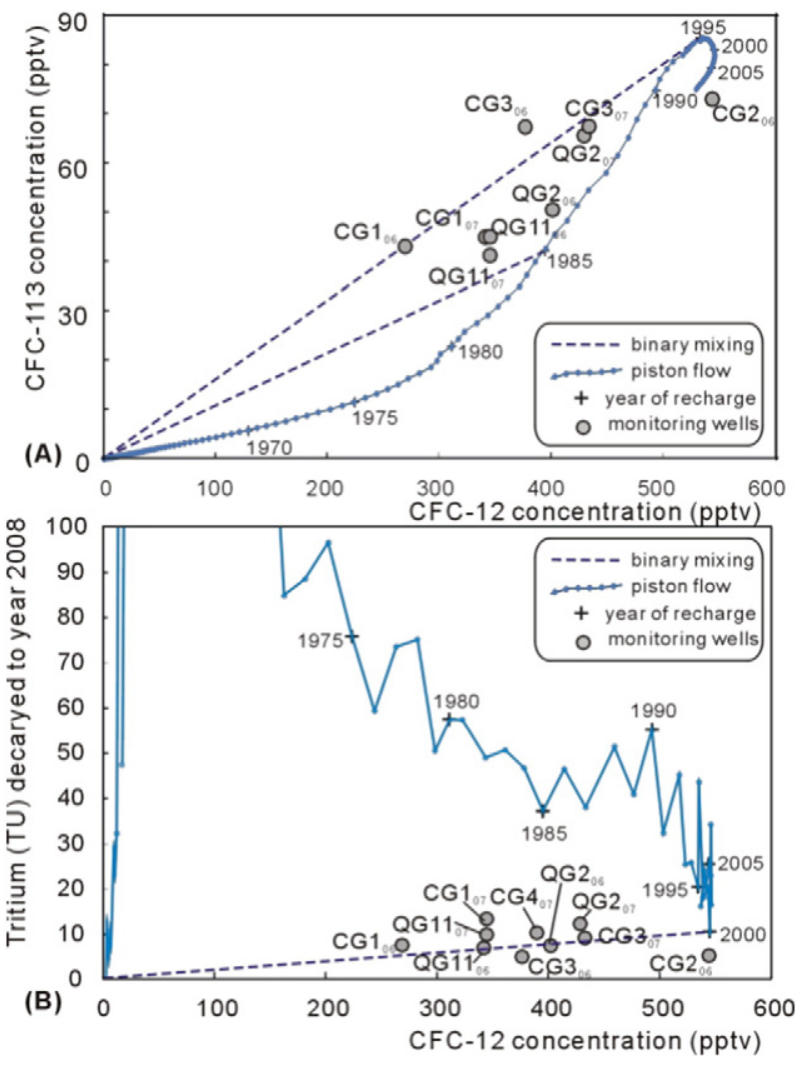

Fig. 12. Relationships between environmental tracer concentrations in groundwaters from the coastal aquifers of the Daweijia area. A. CFC-113 vs. CFC-12; B. ${ }^{3} \mathrm{H}$ vs. CFC-12. CFC data are available at http://water.usgs.gov/lab/. Model lines are included for piston flow and binary mixing between modern (2000) and old (tracer-free) water. The "+" signs on the piston-flow line indicate year of recharge. data. This is due to the calculated mean age of the old component still being very young. The MRT of well CG1 located in the west of well field is 88 years using the EPM model. The mean age of young component in CG1 is 4 years with an old water fraction of 0.64 using the BEP model, and 40 years with an old water fraction of 0.49 using the BDD model.

Wells QG3 and QG4 are situated at a higher elevation in the upstream area of the aquifer. An initial estimate for the dispersion parameter (DP) was obtained by adjusting the parameter value until the DM best matched the measured tritium data. The MRTs obtained using the DM are around 120 years (Table 3). QG3 (Fig. 14c) and QG4, located in the shallow Quaternary aquifer of the upstream area, have relatively lower tritium contents (3.4-5.7 TU). The greater mean ages obtained using the BEP and BDD models with varied old water fraction (about 0.93 and 0.7 , respectively) can be explained by the retarded effects of diffusive exchange between mobile and stagnant water in the aquifer matrix. Additionally, these waters had relatively low nitrate concentrations (less than $100 \mathrm{mg} / \mathrm{L}$ ). The young component of water found using the BDD model and data for wells QG2 and QG5, located near the well field, was found to have a low value for the dispersion parameter $(<0.01)$, suggesting a local origin of that component with MRTs of 53 and 68 years, respectively. The mean age of young component was determined to be $4-7$ years, and 30 years for the BEP and BDD models, respectively. Both wells reported a similar old water fraction (about 0.6). In the past three decades, there has been groundwater depression near the well field making the well screens closer to the point of recharge (where age is zero). Thus, the shallow groundwater in the well field has a relatively young age. For wells QG6, QG8 and QG11, the BEP is more representative of the conditions due to the aquifer in this location being confined by clay. The groundwater at these locations has a mean age of young component of 4-5 years with and old water fraction of 0.5 . This can be verified by the presence of distant flow components with high nitrate contents (more than $250 \mathrm{mg} / \mathrm{L}$ ). Unfortunately, the lack of

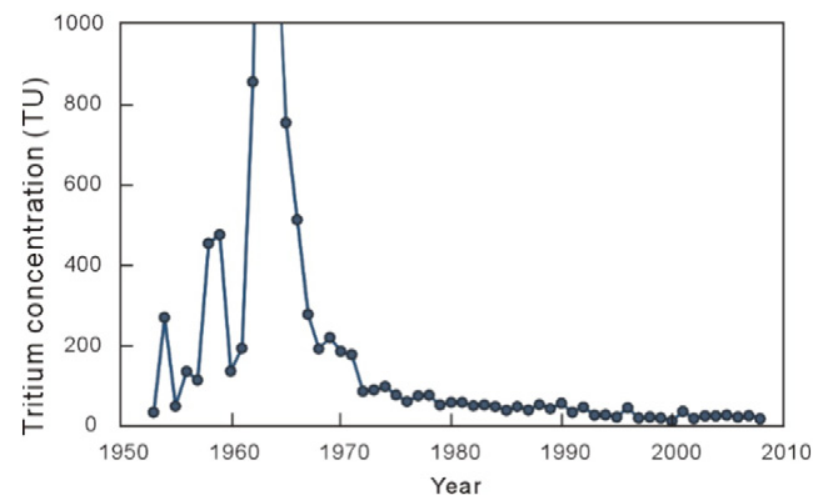

Fig. 13. Re-constructed tritium-input concentration in precipitation at Shijiazhuang. 
Table 3

Model results fitted to the measured tritium data given in Table 2.

\begin{tabular}{|c|c|c|c|c|c|c|c|c|}
\hline Site & Model & $t_{\text {mean }}$ & $t_{\text {young }}$ & $t_{\text {old }}$ & $\beta$ & $D P$ & $\eta$ & $\Sigma(\mathrm{TU})$ \\
\hline \multirow[t]{3}{*}{ CG1 } & EPM & 88 & & & & & 1.96 & 0.61 \\
\hline & BMM-EMM-PFM & 142 & 4 & 220 & 0.64 & & & 0.71 \\
\hline & BMM-DM-DM & 168 & 40 & 303 & 0.49 & 0.8 & & 0.83 \\
\hline \multirow[t]{3}{*}{ CG2 } & EPM & 111 & & & & & 1.63 & 0.66 \\
\hline & BMM-EMM-PFM & 163 & 7 & 225 & 0.72 & & & 0.43 \\
\hline & BMM-DM-DM & 211 & 45 & 285 & 0.70 & 0.8 & & 0.71 \\
\hline \multirow[t]{3}{*}{ CG3 } & EPM & 94 & & & & & 1.88 & 1.26 \\
\hline & BMM-EMM-PFM & 411 & 46 & 460 & 0.88 & & & 1.27 \\
\hline & BMM-DM-DM & 303 & 45 & 321 & 0.93 & 0.8 & & 0.91 \\
\hline \multirow[t]{3}{*}{ CG4 } & EPM & 95 & & & & & 1.84 & 0.42 \\
\hline & BMM-EMM-PFM & 183 & 4 & 260 & 0.70 & & & 0.66 \\
\hline & BMM-DM-DM & 217 & 45 & 311 & 0.65 & 0.8 & & 0.94 \\
\hline \multirow[t]{3}{*}{ CG5,CG12 } & EPM & 84 & & & & & 1.08 & 0.64 \\
\hline & BMM-EMM-PFM & 49 & 6 & 199 & 0.23 & & & 0.23 \\
\hline & BMM-DM-DM & 191 & 28 & 350 & 0.51 & 0.8 & & 1.12 \\
\hline \multirow[t]{3}{*}{ CG7 } & EPM & 61 & & & & & 1.40 & 0.00 \\
\hline & BMM-EMM-PFM & 15 & 1 & 20 & 0.76 & & & 0.00 \\
\hline & BMM-DM-DM & 11 & 5 & 20 & 0.40 & 0.8 & & 0.00 \\
\hline \multirow[t]{3}{*}{ CG10 } & EPM & 76 & & & & & 1.07 & 0.00 \\
\hline & BMM-EMM-PFM & 8 & 1 & 20 & 0.37 & & & 0.00 \\
\hline & BMM-DM-DM & 8 & 1 & 20 & 0.33 & 0.8 & & 0.00 \\
\hline \multirow[t]{3}{*}{ CG20 } & EPM & 295 & & & & & 1.15 & 0.00 \\
\hline & BMM-EMM-PFM & 416 & 45 & 420 & 0.99 & & & 0.33 \\
\hline & BMM-DM-DM & 445 & 45 & 500 & 0.88 & 0.8 & & 0.00 \\
\hline \multirow[t]{3}{*}{ QG2 } & $\mathrm{DM}$ & 53 & & & & 0.002 & & 0.70 \\
\hline & BMM-EMM-PFM & 92 & 7 & 132 & 68.4 & & & 0.00 \\
\hline & BMM-DM-DM & 186 & 30 & 323 & 53.1 & 0.8 & & 1.14 \\
\hline \multirow[t]{3}{*}{ QG3 } & $\mathrm{DM}$ & 125 & & & & 0.23 & & 0.49 \\
\hline & BMM-EMM-PFM & 467 & 40 & 500 & 0.93 & & & 0.41 \\
\hline & BMM-DM-DM & 374 & 50 & 500 & 0.72 & 0.8 & & 0.42 \\
\hline \multirow[t]{3}{*}{ QG4 } & $\mathrm{DM}$ & 119 & & & & 0.219 & & 0.00 \\
\hline & BMM-EMM-PFM & 198 & 4 & 200 & 99.0 & & & 0.05 \\
\hline & BMM-DM-DM & 351 & 30 & 500 & 68.3 & 0.8 & & 0.11 \\
\hline \multirow[t]{3}{*}{ QG5 } & $\mathrm{DM}$ & 68 & & & & 0.033 & & 0.01 \\
\hline & BMM-EMM-PFM & 194 & 4 & 312 & 0.62 & & & 0.00 \\
\hline & BMM-DM-DM & 204 & 30 & 338 & 0.56 & 0.8 & & 0.92 \\
\hline \multirow[t]{3}{*}{ QG8,QG6 } & $\mathrm{DM}$ & 68 & & & & 0.033 & & 1.05 \\
\hline & BMM-EMM-PFM & 100 & 4 & 188 & 0.52 & & & 0.00 \\
\hline & BMM-DM-DM & 149 & 30 & 338 & 0.39 & 0.8 & & 1.04 \\
\hline \multirow[t]{3}{*}{ QG9 } & $\mathrm{DM}$ & 81 & & & & 0.508 & & 0.00 \\
\hline & BMM-EMM-PFM & 277 & 4 & 500 & 0.55 & & & 0.00 \\
\hline & BMM-DM-DM & 115 & 10 & 500 & 0.22 & 0.8 & & 0.00 \\
\hline \multirow[t]{3}{*}{ QG11 } & DM & 67 & & & & 0.03 & & 0.55 \\
\hline & BMM-EMM-PFM & 254 & 5 & 500 & 0.50 & & & 0.32 \\
\hline & BMM-DM-DM & 187 & 27 & 307 & 0.57 & 0.8 & & 0.75 \\
\hline
\end{tabular}

$\mathrm{DM}$ is dispersion model; EPM is the exponential piston-flow model; BMM-EMM-PFM is binary exponential and piston-flow mix; BMM-DM-DM is binary dispersion model under an assumption of a two-component flow. $\beta$, the fraction of old (tritium-free) flow component in total flow; $D P$, the dispersion parameter; $\eta$, the ratio of the total volume of the system to the volume with exponential flow; $\sum$, goodness of fit, which is the square root of differences between the observed data and the simulated result, divided by the number of data; $t_{\text {mean }}$, mean age; $t_{\text {young, }}$, mean age of young component; $t_{\text {old }}$, calculated mean age of old component. For the model related to BMM, the $t_{\text {mean }}$ can be estimated from the relationship: $t_{\text {mean }}=(1-\beta) \times t_{\text {young }}+\beta \times t_{\text {old }}$ (Zuber et al., 2001).

historic tritium observations precluded more detailed model calibrations of MRTs in this study.

The chemical and stable isotopic compositions of groundwater samples in the Quaternary and carbonate aquifers show similar characteristics, indicating good hydraulic connection between two aquifers. Combined with the different LPM models (Fig. 15), the binary mixing model can reflect the actual conceptual model. A feasible model may be found by comparing the simulated and measured tritium results (Fig. 15). The model with consistently lower errors can be regarded as the most conceptually feasible model in this area. Generally, the BEP model can most reasonably describe the carbonate aquifer in which very young water that travels along conduit features mixes in a production well with water from the rock matrix. We also found that for the water samples with higher tritium contents ranging between 10 and $16 \mathrm{TU}$, the BEP model result is more feasible than those obtained using the BDD model. Thus, apart from groundwater at wells CG3, CG20 and
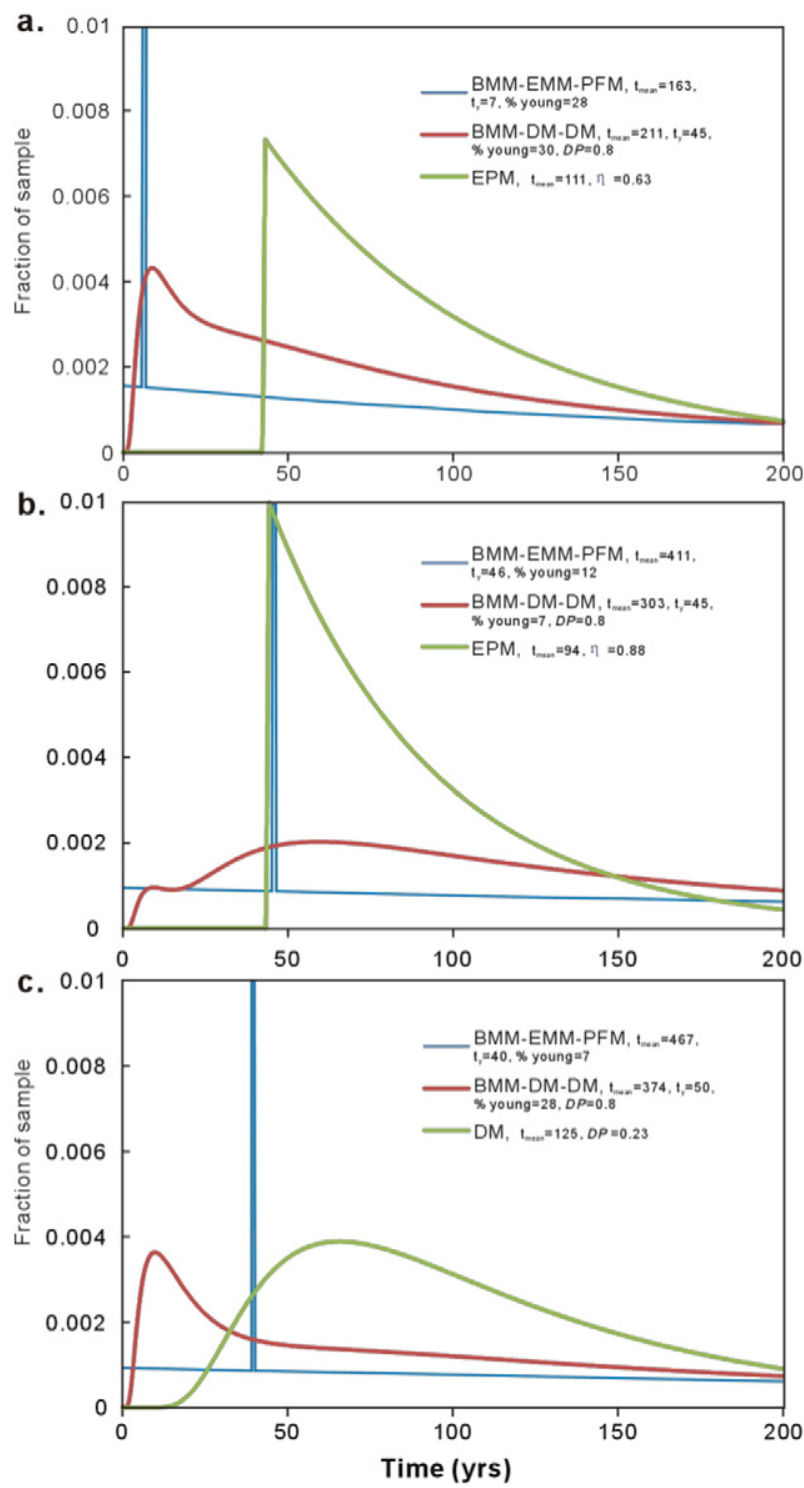

Fig. 14. Simulated groundwater age distributions for a CG2, b CG3, and c QG3. The fraction of the sample represents the proportion of age corresponding to a given age increment. Individual curves correspond to different models as shown in the graph.

QG3, the mean age of the young component ranges from 1 to 7 years with a wide range of old water fractions (0.23-0.99). CG3 and QG3 are likely contain a large component of old water due to their relatively high mean age of young component (around 50 years).

The MRTs obtained from the tritium contents of groundwater samples range from 8 to 467 years; whereas the fraction of old water varies between 0.22 and 0.99 . The presence of nitrate in the shallow QA and the deep COA, and the relatively wide range of the MRTs indicate the coastal carbonate aquifer creates a complex mixture of waters existing in different porosities (conduits, fissures, matrix). Production wells investigated in this study have been used for public supply and have long screened intervals (more than $30 \mathrm{~m}$ ) at a large depth. It is likely that no flow lines exist with extremely short transit times.

\subsection{Nitrate transport pattern in groundwater flow system}

Groundwater in carbonate aquifers is particularly susceptible to agricultural activities, which can readily cause nitrate contamination (Coxon et al., 1999; Katz, 2004). The anthropogenic input (e.g., agricultural fertilizer, septic tank drainage, untreated sewage effluent) may be responsible for the elevated nitrate concentrations of the groundwater underlying the 


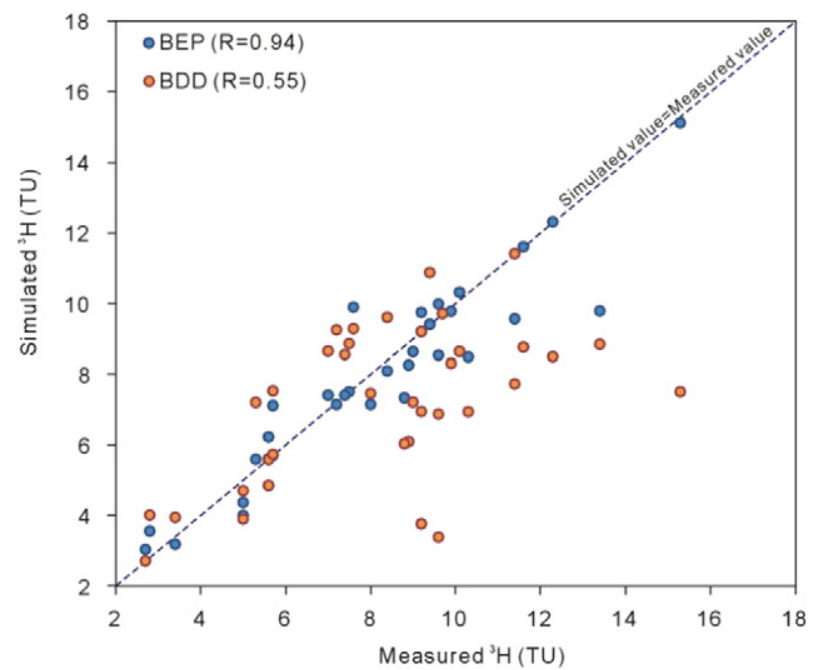

Fig. 15. Scatter plots for comparing the measured ${ }^{3} \mathrm{H}$ data and the simulated ${ }^{3} \mathrm{H}$ data for different LPM models. BEP is the binary exponential and piston-flow mixing model (BMM-EMM-PFM); BDD is the binary mixing model with a two-component dispersion model (BMM-DM-DM).

Daweijia well field in the past several decades. The total $\mathrm{NO}_{3}^{-}$concentrations $\left(\mathrm{NO}_{3, t}\right)$ of groundwater can be described as follows:

$\mathrm{NO}_{3, t}=\mathrm{NO}_{3, r}+\mathrm{NO}_{3, a}+\mathrm{NO}_{3, d}+\mathrm{NO}_{3, \mathrm{~s}}$

where $\mathrm{NO}_{3, r}-\mathrm{NO}_{3}^{-}$contributed from rainwater; $\mathrm{NO}_{3, a}-\mathrm{NO}_{3}^{-}$contributed from agricultural fertilizer utilization; $\mathrm{NO}_{3, d}-\mathrm{NO}_{3}^{-}$contributed from domestic wastes (e.g., septic tank leakage, sewage effluent); $\mathrm{NO}_{3, \mathrm{~s}}-$ $\mathrm{NO}_{3}^{-}$contributed from seawater intrusion. The mean volume-weighted $\mathrm{NO}_{3}^{-}$concentration of rainwater is $\sim 3.4 \mathrm{mg} / \mathrm{L}$ in this area (Zhang et al., 2012), and the estimated $\mathrm{NO}_{3}{ }^{-}$concentrations contributed from rainwater is only $2.7 \mathrm{mg} / \mathrm{L}$ annually according to the water balance calculations in the local groundwater flow system (CGS, 2007). This is mainly recharged from precipitation infiltration, with $78.3 \%$ of the total recharge water volume. Compared with $\mathrm{NO}_{3, t}$ concentration of as much as several hundreds, $\mathrm{NO}_{3, r}$ can be negligible. Thus, the $\mathrm{NO}_{3, t}$ can be expressed by:

$\mathrm{NO}_{3, t}=\mathrm{NO}_{3, a}+\mathrm{NO}_{3, d}+\mathrm{NO}_{3, s}$

The highest $\mathrm{NO}_{3}^{-}$concentrations occur in the aquifers underlying agricultural fields (e.g., QG2, CG9). Some wells (e.g., CG1, CG7, CG10, CG12) show a high chloride concentration as well as low nitrate concentrations and low $\mathrm{NO}_{3} / \mathrm{Cl}$ ratios (Fig. 11), indicating that the groundwater salinity is likely derived from seawater intrusion. The recent seawater has low tritium contents (3.8 TU in Nov.2005, measured in this study) with distinct nitrate concentrations (averagely $370 \mathrm{mg} / \mathrm{L}$ in February, and $<62 \mathrm{mg} / \mathrm{L}$ in August, Chen, 2008) and $\mathrm{NO}_{3} / \mathrm{Cl}$ ratios ( 0.01). The highest Fsw occurred in wells CG10 (4.7\%) and CG7 (4.6\%). Thus, the highest contribution of $\mathrm{NO}_{3}^{-}$from seawater is unlikely to exceed $20 \mathrm{mg} / \mathrm{L}$, indicating that the seawater intrusion will be very limited for modifying groundwater quality in the coastal aquifers. Increased nitrate concentrations in most of the collected groundwater samples were characterized by a narrow range $\left(-8.5 \sim-7.0 \%\right.$ o of $\delta^{18} \mathrm{O}$ values (Fig. 16) with varying tritium contents between the wet and dry seasons. This indicates groundwater with lower evaporation prior to recharge originating from a local small area rather than a regional scale. In the Daweijia area, local groundwater is the sole source of irrigation water, and the irrigation does not significantly modify the $\delta^{18} \mathrm{O}$ values and ${ }^{3} \mathrm{H}$ content of the groundwater (Plummer et al., 2000; Horst et al., 2008). As discussed above, the $\mathrm{NO}_{3}^{-}$concentration of groundwater contributed from the Bohai seawater does not exceed $20 \mathrm{mg} / \mathrm{L}$, indicating the rise of the salinity is derived from agricultural return flow as an important recharge source rather than seawater intrusion in the coastal aquifers. Dissolved oxygen in groundwater ranges between 1.3 and $8.6 \mathrm{mg} / \mathrm{L}$ (Aug. 2010), indicating an aerobic environment, hence denitrification is presumed to be negligible. Groundwater shows higher tritium contents in the wet season with lower tritium contents in dry season (Fig. 16b), indicating there might be significant precipitation infiltration and fluctuating water tables in this area. The mean age of the young component of the investigated groundwater ranged from 1 to 46 years (BEP model in Table 3 ).

The groundwaters under the Deweijia area can be classified in four groups. Group A, evidenced by CG3, CG5 and CG12, is characterized by a wide range of tritium contents (3-15 TU), depleted $\delta^{18} \mathrm{O}$ values in the wet season and relatively low $\mathrm{NO}_{3}^{-}$concentrations $\left(\mathrm{NO}_{3}^{-}\right.$ $<100 \mathrm{mg} / \mathrm{L}$ ). This indicates that highly connected conduits may be occurring at these sites, resulting in a quick response to the rainfall. CG5 and CG12, which are located near a fault zone and recharged from higher elevations to the south, have slightly increased $\mathrm{NO}_{3}^{-}$concentrations with short MRT ( 49 years) due to the leaching of fertilizers. Their brackish nature suggests certain mixing with seawater $\left(F_{S W}\right.$ between 2 and 3\%). The water at well CG3 changed from brackish in Nov.2005 and Jun. 2006 to fresh in Jul. 2007, with relatively lower $\mathrm{NO}_{3}^{-}$concentrations (less than $100 \mathrm{mg} / \mathrm{L}$ ). This indicates that apart from the agricultural pollution, the decreased salinity in CG3 may be caused by the reversing of seawater intrusion. This has been reduced by controlling abstraction after 2001 in the well field. Compared with CG2, which has higher $\mathrm{NO}_{3}^{-}$concentrations (up to $357 \mathrm{mg} / \mathrm{L}$ ) and good hydraulic connection with shallow groundwater, the wells in Group A have stable $\mathrm{NO}_{3}^{-}$concentrations in recent years. Group A may be dominated by the lateral flow with relatively stable $\mathrm{NO}_{3}^{-}$concentrations and $\mathrm{NO}_{3, t}$ can be expressed by:

$\mathrm{NO}_{3, t}=\mathrm{NO}_{3, a}+\mathrm{NO}_{3, s}$.

Group B, including groundwater obtained at wells CG1, CG2, CG7, CG10, and QG11 (Fig. 16b, c), is likely to have been affected by seawater intrusion and to some extent, rainfall infiltration and irrigation return flow. The rainfall infiltration can cause the higher tritium content, and the irrigation return flow can result in an increased nitrate concentration. Wells CG2 and CG7, located in the well field, have a higher nitrate concentration but a similar range of tritium content. This suggests hydraulic connections with CG1, QG2 and QG5. This also indicates there might be a vertical preferential flow path through CG2 with a higher $\mathrm{NO}_{3}^{-}$concentration. This is likely attributable to a $\mathrm{NO}_{3}^{-}$bearing source, e.g., septic tanks or sewage effluent. In the wet season, the pollutants can be rapidly flushed by rainfall into the deep aquifer through the preferential flow paths. CG2 is connected to shallow, brackish groundwater with $F_{S W}(1.5-1.8 \%)$. This indicates that this well is simultaneously affected by seawater intrusion and anthropogenic pollution. CG1 also has a higher $F_{S W}(2.9-3.2 \%)$. The $\mathrm{NO}_{3, t}$ of Group B can be expressed by:

$\mathrm{NO}_{3, t}=\mathrm{NO}_{3, a}+\mathrm{NO}_{3, d}+\mathrm{NO}_{3, s}$.

Based on the $F_{S W}$ distribution, we can conclude that there are potentially two preferential flow paths underlying the carbonate aquifers, one is located in the northern part of the study area, running from the coastline through CG1, CG2, to CG7; and the other one is located in the southern part and along the fault (F3) and F1 to reach CG5 and CG12. This is consistent with the previous research by Wu and Jin (1990), which used geophysical methods to identify the potential passageway of seawater intrusion in the coastal aquifers. CG2 and CG3 have relatively longer MRTs (over 150 years) as the solute flow to the location of the monitoring wells is dominated by stagnant water pumped from the limestone matrix. This water has a different young fraction in the groundwater. There is possibly a pollution source distributed around the recharge area, which is connected to the screen interval of CG2. It results in the relatively higher $\mathrm{NO}_{3}^{-}$concentration in $\mathrm{CG} 2$ than that in CG3. This 
suggests that in these areas, the groundwater age distributions are complex, and MRTs are not a good indicator of the flow patterns, i.e. the whole age distribution requires quantification.

Generally, in the dry season, groundwater has a relatively low $\mathrm{NO}_{3}^{-}$ concentration with low tritium content (Fig. 16c). Conversely, in the wet season groundwater (e.g., CG1, QG11, QG2, QG5) (Fig. 16c) displayed higher tritium contents and higher nitrate concentrations, indicating that the sources of $\mathrm{NO}_{3}^{-}$not only originate from fertilizer application during irrigation but also the from other sources (e.g., septic tank, cesspool, sewage effluent). The higher fraction of old groundwater and a relatively lower fraction of young water can dilute the pollutants in the dry season. In the wet season, the pollutants (i.e. $\mathrm{NO}_{3}^{-}$from septic tank or sewage effluent) can be flushed into the aquifer.

Group C, defined as shallow groundwater (i.e. QG2, QG5, QG12) near the well field area, has a higher $\mathrm{NO}_{3}^{-}$concentration directly from surface pollution and readily responds to rainfall as demonstrated by higher tritium contents. The $\mathrm{NO}_{3, t}$ of Group $\mathrm{C}$ can be expressed by:

$\mathrm{NO}_{3, t}=\mathrm{NO}_{3, a}+\mathrm{NO}_{3, d}$

Group D, including wells CG4, QG3 and QG4, which are located in the upstream area, is characterized by fresh groundwater with relatively lower $\mathrm{NO}_{3}^{-}$concentrations during the four sampling campaigns. CG4 may be controlled by the lateral flow near the fault zone and has MRT of 183 years with a mean age of the young component of 4 years. QG3 and QG4 have lower tritium contents and $\mathrm{NO}_{3}^{-}$concentrations due to matrix diffusion. The $\mathrm{NO}_{3, t}$ of Group $\mathrm{D}$ can be expressed by:

$\mathrm{NO}_{3, t}=\mathrm{NO}_{3, a}$.

Patterns of the $\mathrm{NO}_{3}^{-}$transport through a complex aquifer depend on the types and time frames of nitrogen loading, local hydrogeologic conditions (i.e. recharge patterns, groundwater flow paths, velocities, and MRT), hydrologic and climatic variations, and the biogeochemical parameters that control the related reactions (Katz, 2004). Although the apparent age or MRT of groundwater does not necessarily represent the age of the nitrate transport (Katz, 2004), it is of interest that the shallow groundwaters (i.e. QG2 and QG5) tend to have higher nitrate concentrations (>300 mg/L, even up to $517 \mathrm{mg} / \mathrm{L}$ ) with mean age of young component (4-7 years), while lower nitrate concentrations $(<100 \mathrm{mg} / \mathrm{L})$ correspond to greater MRT (198-467 years with $t_{\text {young }}=$ $4-40$ years and old water fractions of around 0.65 , i.e. QG3 and QG4) in the upstream area. It suggests that the contribution of elevated nitrate concentrations is from more recent recharge for shallow groundwater near the well field. This may also suggest that locations with greater MRTs in the shallow aquifers may be susceptible to elevated $\mathrm{NO}_{3}^{-}$concentrations in the future. However, there is no significant relationship between the MRT and the $\mathrm{NO}_{3}^{-}$concentrations in the carbonate aquifer. This may be due to the samples representing a number of complex flow paths containing both young nitrate bearing water and old nitrate free water. In these cases, more complex descriptions of residence time may be required to describe susceptibility to nitrate contamination. These methods generally require more extensive data sets than are available at this site presently.

\section{Summary and conclusions}

The aquifer systems in the Daweijia area are characterized by a shallow Quaternary aquifer and a deep carbonate aquifer, with a wide range of $\mathrm{NO}_{3}^{-}$concentrations from 32.6 to $521.3 \mathrm{mg} / \mathrm{L}$ (mean value $191.2 \mathrm{mg} / \mathrm{L}$ ). These concentrations significantly exceed the safe drinking guidelines $(20 \mathrm{mg} / \mathrm{L})$ in China. This study applied, chemical analysis and CFCs and ${ }^{3} \mathrm{H}$ dating methods to interpret the relationship between groundwater flow and $\mathrm{NO}_{3}^{-}$transport for identifying the potential groundwater flow patterns and contaminant sources. CFC concentrations have been used to identify the irrigation effect on groundwater systems through comparison with tritium content in groundwater samples, and the old groundwater existing in karst aquifers. All groundwater samples have measurable tritium levels with the wide range (2.7-15.3 TU) of tritium content, indicating rapid groundwater circulation exists within the coastal aquifer systems.

Different LPM methods (i.e., EPM, BEP, BDD, DM) were employed to estimate the groundwater MRTs in the study area. The BEP model was confirmed to yield the feasible MRTs for both of Quaternary and carbonate aquifers. Based on the estimated results, there is a good inverse relation between groundwater MRTs and the $\mathrm{NO}_{3}^{-}$concentrations in the shallow Quaternary aquifers. The elevated nitrate concentrations can be attributed to more recent recharge to shallow groundwater of the study area. The relatively old ages in the upstream area may be caused by the delay effects of the diffusive flow exchange between mobile and stagnant water in the aquifer matrix (Zuber et al., 2001). However, there is no significant relationship between the MRTs and the $\mathrm{NO}_{3}^{-}$concentrations existing in the carbonate aquifer system, due to the complicated porosity, groundwater age distribution and contaminant source areas. The youngest carbonated groundwater located in the southern hills has been controlled by the lateral flow along the fault zone. Provided that the groundwater MRTs can be as much as several decades,
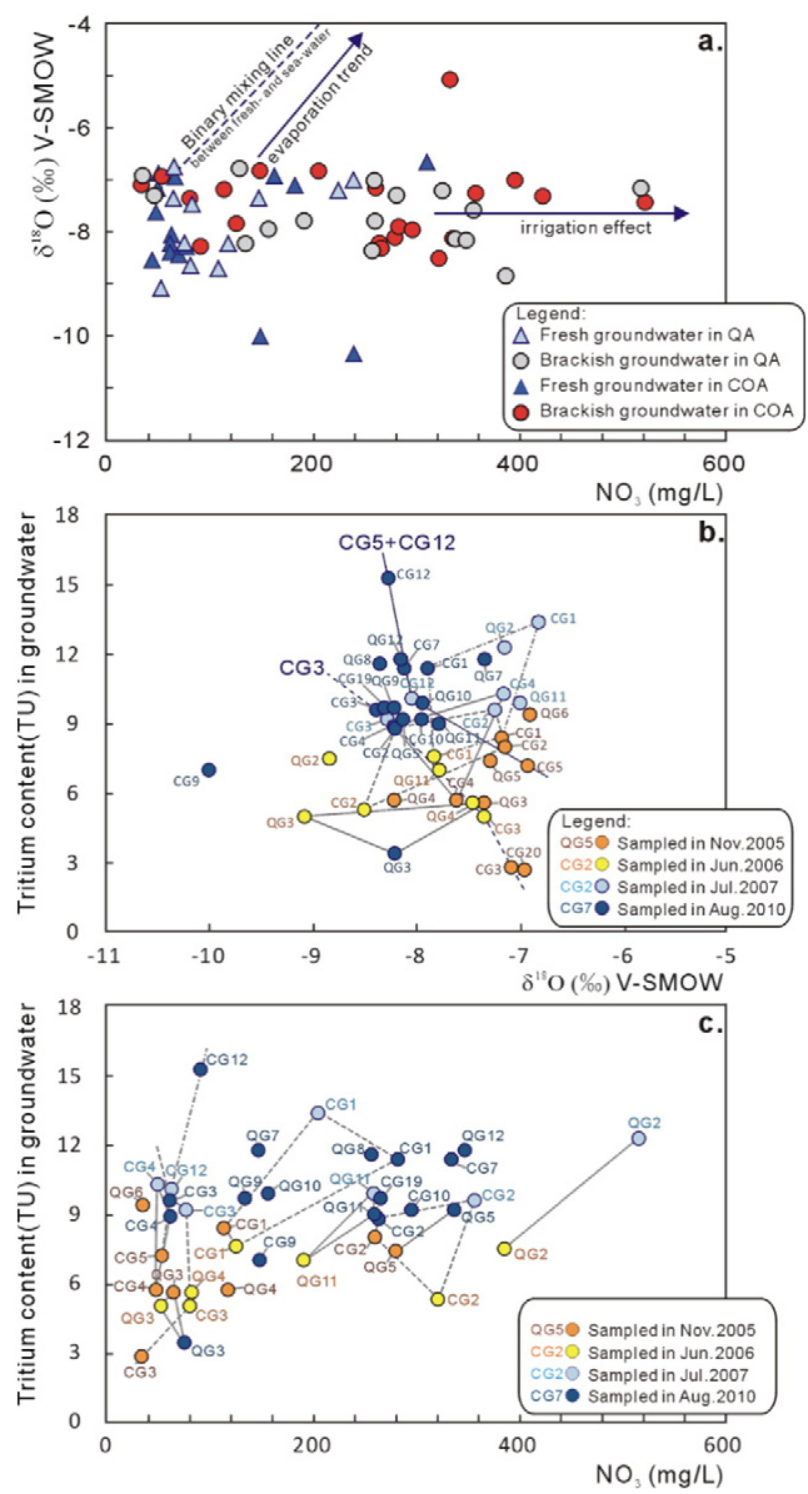

Fig. 16. Relationships between $\delta^{18} \mathrm{O}$ and $\mathrm{NO}_{3}^{-}$concentrations (a); tritium contents and $\delta^{18} \mathrm{O}$ values (b); tritium contents and $\mathrm{NO}_{3}^{-}$concentrations (c). The dashed lines connect samples obtained from the same wells. 
nitrate in groundwater system without denitrification effects could accumulate and transport for tens of years through the complex carbonate aquifer matrix due to successive inputs of nitrogen from various sources. The fraction of young components which range from 0.10 to 0.78 (mean 0.33 ) suggests that relatively old groundwater is extracted at some wells. The groundwater within the coastal carbonate aquifer is particularly susceptible to anthropogenic pollution (e.g., successive irrigation cycles by pumping groundwater, septic tank drainage, and sewage effluent leaching) and seawater intrusion.

Although further investigation should be carried out for accurately determining the highly complex relation between $\mathrm{NO}_{3}^{-}$concentrations and hydrologic conditions, some qualitative explanations for our observations are that (i) the $\mathrm{NO}_{3}^{-}$concentrations of most deep carbonated groundwater within the well field resulted from agricultural fertilizer application, domestic waste leakage (e.g., septic tank drainage, sewage effluent leaching) and limited seawater intrusion; (ii) the shallow groundwater near the well field shows pollution from fertilizer utilization and domestic input; (iii) the carbonated groundwater near the fault zone in the southern part of the aquifer has been subjected to contamination from fertilizer application and seawater intrusion; (iv) the groundwater within the upstream aquifers has likely suffered from only fertilizer application. Generally, the contribution from seawater intrusion on modifying groundwater quality is very limited in this area under the water-management practices, e.g., controlling extraction after 2001 (Song, 2013). Although the fault zone can provide the preferential flow path for seawater intrusion in this area, the areal extent of seawater intrusion is less than previously reported in Yang (2011) and Zhao et al. (2012). The anthropogenic inputs into the coastal aquifers should be mainly responsible for the groundwater contamination, particularly for nitrate contamination. For the future groundwater management strategies, the more detailed investigation on types, amount, and timing of multiple pollution sources and practices that potentially leach into the aquifers should be implemented for the benefit of maximum protection from further contamination in such areas.

\section{Acknowledgments}

This research was financially supported by the strategic science and technology project of the Exploring Advanced Discipline (No. 2012QY007) in the Institute of Geographic Sciences and Natural Resources Research, Chinese Academy of Sciences, and partially supported by the National High Technology Research and Development Program of China ("863 Program") (No. 2012AA062603) and a groundwater survey project entitled "Assessment of Vulnerability and Investigation of Environmental Geology in the Key Section of Circum-Bohai-Sea Region (No.1212010540501)". The sampling campaigns were supported by Tianjin Institute of Geology and Mineral Resources and Liaoning Hydrological and Engineering Geological Prospecting Academy, Dalian. The authors are indebted to Mr. Yang Jilong, Dr. Liu Xin, Dr. Xie Hailan and Mr. Pan Tong for their help and support during water sampling and monitoring in the field and data collection.

\section{References}

Andrews, W.J., 1994. Nitrate in ground water and spring water near four diary farms in North Florida, 1990-93. U.S. Geological survey. Water-Resources Investigations Report 94-4162, pp. 14-30.

Appelo, C.A.J., Postma, D., 2005. Geochemistry, Groundwater and Pollution. 2nd edition. A.A. Balkema Publishers, Leiden, The Netherlands, pp. 242-247 (CRC Press, Taylor \& Francis Group).

Barlow, P.M., 2003. Ground water in freshwater-saltwater environments of the Atlantic coast. U.S. Geological Survey circular 1262, pp. 31-33.

Bouchaou, L., Michelot, J.L., Vengosh, A., Hsissou, Y., Qurtobi, M., Gaye, C.B., Bullen, T.D., Zuppi, G.M., 2008. Application of multiple isotopic and geochemical tracers for investigation of recharge, salinization, and residence time of water in the Souss-Massa aquifer, southwest of Morocco. J. Hydrol. 352, 267-287.

Busenberg, E., Plummer, L.N., 1992. Use of chlorofluorocarbons $\left(\mathrm{CCl}_{3} \mathrm{~F}\right.$ and $\left.\mathrm{CCl}_{2} \mathrm{~F}_{2}\right)$ as hydrologic tracers and age-dating tools: the alluvium and terrace system of centra Oklahoma. Water Resour. Res. 28, 2257-2283.
Busenberg, Eurybiades, Weeks, E.P., Plummer, L.N., Bartholemay, R.C., 1993. Age dating ground water by use of chlorofluorocarbons $\left(\mathrm{CCl}_{3} \mathrm{~F}\right.$ and $\left.\mathrm{CCl}_{2} \mathrm{~F}_{2}\right)$, and distribution of chlorofluorocarbons in the unsaturated zone. Snake River Plain aquifer, Idaho National Engineering Laboratory, Idaho: U.S. Geological Survey Water-Resources Investigations Report 93-4054 (47 pp.).

Cary, L., Petelet-Giraud, E., Bertrand, G., Kloppmann, W., Aquilina, L., Martins, V., Hirata, R., Montenegro, S., Pauwels, H., Chatton, E., Franzen, M., Aurouet, A., Team, 2015. Origins and processes of groundwater salinization in the urban coastal aquifers of Recife (Pernambuco, Brazil): a multi-isotope approach. Sci. Total Environ. 530-531, 411-429.

Cerar, S., Urbanc, J., 2013. Carbonate chemistry and isotope characteristics of groundwater of Ljubljansko Polje and Ljubljansko Barje aquifers in Slovenia. Sci. World J. 1-11, 948394.

CGS, 2007. Assurance Report of Water Supply in Dalian City (in Chinese). Geological survey institute of Liaoning Province, pp. 38-44.

Chang, Y.E., Li, G.Z., 2011. The characteristics of seawater intrusion at NanLiu River Delta in Beihai City and its effect on groundwater. J. Anhui Agric. Sci. 39 (18), 11057-11060 (in Chinese with English abstract).

Charideh, A., Rahman, A., 2007. Environmental isotopic and hydrochemical study of water in the karst aquifer and submarine springs of the Syrian coast. Hydrogeol. J. 25, 351-364.

Chen, C.T.A., 2008. Distributions of nutrients in the East China Sea and the South China Sea connection. J. Oceanogr. 64, 737-751.

Clark, I., Fritz, P., 1997. Environmental Isotopes in Hydrogeology. Lewis Publishers, Boca Raton, New York

Coxon, C., Lin, X.Y., Liao, Z.S., Ellaway, M., Finlayson, B., Webb, J., Drew, D., Audra, P., Libra, R.D., Hallberg, G.R., Leon, L.F.M., Diaz, J.G., Hardwick, P., Gunn, J., 1999. Agriculturally induced impacts. In: Drew, D.P., Hotzl, H. (Eds.), Karst Hydrogeology and Human Activities: Impacts, Consequences and ImplicationsInternational contributions to hydrogeology vol. 20. Balkema, Rotterdam, pp. 37-80.

Craig, H., 1961. Standard for reporting concentration of deuterium and oxygen-18 in natural water. Science 133, 1833-1834.

Cruz-Fuentes, T., Cabrera, Mdel C., Heredia, J., Custodio, E., 2014. Groundwater salinity and hydrochemical processes in the volcano-sedimentary aquifer of La Aldea, Gran Canaria, Canary Islands, Spain. Sci. Total Environ. 484, 154-166.

Dansgaard, W., 1964. Stable isotopes in precipitation. Tellus 16, 436-468.

de Montety, V., Radakovitch, O., Vallet-Coulomb, C., Blavoux, B., Hermitte, D., Valles, V., 2008. Origin of groundwater salinity and hydrogeochemical processes in a confined coastal aquifer: case of the Rhône delta (South France). Appl. Geochem. 23, 2337-2349.

Eberts, S.M., Böhlke, J.K., Kauffman, L.J., Jurgens, B.C., 2012. Comparison of particletracking and lumped-parameter age-distribution models for evaluating vulnerability of production wells to contamination. Hydrogeol. J. 20, 263-282.

Eichinger, L., Forster, M., Rast, H., Rauert, W., Wolf, M., 1980. Experience gathered in lowlevel measurement of $3 \mathrm{H}$ in water. Low-level ${ }^{3} \mathrm{H}$ Measurement, IAEA-TECDOC-346. IAEA, Vienna, Austria, pp. 43-64.

El Yaoutia, E., El Mandour, A., Khattach, D., Benavente, J., Kaufmann, O., 2009. Salinization processes in the unconfined aquifer of Bou-Areg (NE Morocco): a geostatistical, geochemical, and tomographic study. Appl. Geochem. 27, 22-36.

Ettayfi, N., Bouchaou, L., Michelot, J.L., Tagma, T., Warner, N., Boutaleb, S., Massault, M., Lgourna, Z., Vengosh, A., 2012. Geochemical and isotopic (oxygen, hydrogen, carbon, strontium) constraints for the origin, salinity, and residence time of groundwater from a carbonate aquifer in the Western Anti-Atlas Mountains, Morocco. J. Hydrol. 438-439, 97-111.

Falcone, R.A., Falgiani, A., Parisse, B., Petitta, M., Spizzico, M., Tallini, M., 2008. Chemical and isotopic $\left(\delta^{18} \mathrm{O} \%, \delta^{2} \mathrm{H} \%, \delta^{13} \mathrm{C} \%\right.$, $\left.{ }^{222} \mathrm{Rn}\right)$ multi-tracing for groundwater conceptual model of carbonate aquifer (Gran Sasso INFN underground laboratory - central Italy). J. Hydrol. 357, 368-388.

Fan, J.J., 1984. Seawater intrusion and calculation of groundwater exploitation in the karst area of the west JinXian, Dalian. Hydrogeol. Eng. Geol. 1, 3-6 (in Chinese with English abstract).

Frondini, F., 2008. Geochemistry of regional aquifer systems hosted by carbonateevaporite formations in Umbria and southern Tuscany (central Italy). Appl. Geochem. 23, 2091-2104.

Frot, E., van Wesemael, B., Vandenschrick, G., Souchez, R., Benet, A.S., 2007. Origin and type of rainfall for recharge of a karstic aquifer in the the western Mediterranean: a case study from the Sierra de Gador-Campo de Dalias (southeast Spain). Hydrol. Process. 21, 359-368.

Ghiglieri, G., Carletti, A., Pittalis, D., 2012. Analysis of salinization processes in the coastal carbonate aquifer of Porto Torres (NW Sardinia, Italy). J. Hydrol. 432-433, 43-51.

Guo, Y.H., Shen, Z.L., Zhong, Z.S., 1995. Downward movement of saline groundwater and its relationship with diluted saline groundwater in shallow aquifers in Hebei Plain. Hydrogeol. Eng. Geol. 2, 8-12 (in Chinese with English abstract).

Han, D.M., Kohfahl, C., Song, X.F., Xiao, G.Q., Yang, J.L., 2011. Geochemical and isotopic evidence for palaeo-seawater intrusion into the south coast aquifer of Laizhou Bay, China. Appl. Geochem. 26, 863-883.

Han, D.M., Song, X.F., Currell, M.J., Tsujimura, M., 2012. Using chlorofluorocarbons (CFCs) and tritium to improve conceptual model of groundwater flow in the South Coast Aquifers of Laizhou Bay, China. Hydrol. Process. 26 (23), 3614-3629.

Han, D.M., Song, X.F., Currell, M.J., Yang, J.L., Xiao, G.Q., 2014. Chemical and isotopic constraints on evolution of groundwater salinization in the coastal plain aquifer of Laizhou Bay, China. J. Hydrol. 508, 12-27.

Horst, A., Mahlknecht, J., Merkel, B.J., Aravena, R., Ramos-Arroyo, Y.R., 2008. Evaluation of the recharge processes and impact of irrigation on groundwater using CFCs and radiogenic isotopes in the Silao-Romita basin, Mexico. Hydrogeol. J. 16, 1601-1614

IAEA (International Atomic Energy Agency), 1992. Statistical treatment of environmental isotope data in precipitation. Technical Report Series, No.331. IAEA, Vienna, p. 720. 
Jin, Y.J., Wu, Q., 1990. Application of the Electrical logging of well fluid in determining the vertical heterogeneity of seawater intrusion. J. Hebei Coll. Geol. 13 (1), 69-73 (in Chinese with English abstract)

Jones, B.F., Vengosh, A., Rosenthal, E., Yechieli, Y., 1999. Geochemical investigations. In: Bear, et al. (Eds.), Seawater Intrusion in Coastal Aquifers - Concepts, Methods and Practices, pp. 51-72.

Jones, I.C., Banner, J.L., Humphrey, J.D., 2000. Estimating recharge in a tropical karst aquifer. Water Resour. Res. 36 (5), 1289-1299.

Jurgens, B.C., Böhlke, J.K., Eberts, S.M., 2012. TracerLPM (Version 1): An Excel® Workbook for Interpreting Groundwater Age Distributions from Environmental Tracer Data: U.S. Geological Survey Techniques and Methods Report 4-F3. p. 60.

Katz, B.G., 2004. Sources of nitrate contamination and age of water in large karstic springs of Florida. Environ. Geol. 46, 689-706.

Katz, B.G., Chelette, A.R., Pratt, T.R., 2004. Use of chemical and isotopic tracers to assess nitrate contamination and ground-water age, Woodville Karst Plain, USA. J. Hydrol. 289, 36-61.

Khaska, M., La Salle, C.L.G., Lancelot, J., Mohamad, A., Verdoux, P., Noret, A., et al., 2013. Origin of groundwater salinity (current seawater vs. saline deep water) in a coastal karst aquifer based on $\mathrm{Sr}$ and $\mathrm{Cl}$ isotopes. Case study of the La Clape massif (southern France). Appl. Geochem. 37, 212-227.

LNR, 2006. Report of Seawater Intrusion in the Daweijia Area (2004-2005). Liaoning Survey Academy of Geology and Mineral Resources, Shenyang in Liaoning Province, China, pp. 12-18.

Long, A.J., Putnam, L.D., 2009. Age-distribution estimation for karst groundwater: issues of parameterization and complexity in inverse modeling by convolution. J. Hydrol. 376, 579-588.

Long, A.J., Sawyer, J.F., Putnam, L.D., 2008. Environmental tracers as indicators of karst conduits in groundwater in South Dakota, USA. Hydrogeol. J. 16, 263-280.

Lü, G., 1980. Seawater intrusion problem of Lüda City. Hydrogeol. Eng. Geol. 4, 50 (in Chinese).

Lü, G., Zhao, L.B., Sun, X.Z., Tan, D.F., 1981. Periodic Summary Report on Investigating the Environmental Hydrogeology in Dalian Area (in Chinese). The Second Institute of hydrogeology and engineering geology, Liaoning Bureau of Geology, pp. 48-66.

Maloszewski, P., Zuber, A., 1996. Lumped parameter models for the interpretation of environmental tracer data. Manual on Mathematical Models in Isotope Hydrology. IAEA-TECDOC-910 with Supplement. IAEA, Vienna, Austria, pp. 9-58.

Mangin, A., 1994. Karst hydrogeology. In: Gilbert, J. (Ed.), Ground-Water Ecology. Elsevier, New York, pp. 43-67.

McCaffrey, M.A., Lazar, B., Holland, H.D., 1987. The evaporation path of sea water and coprecipitation of $\mathrm{Br}-$ and $\mathrm{K}+$ with halite. J. Sediment. Petrol. 57, 928-937.

Merchán, D., Auqué, L.F., Acero, P., Gimeno, M.J., Causapé, J., 2015. Geochemical processes controlling water salinization in an irrigated basin in Spain: identification of natura and anthropogenic influence. Sci. Total Environ. 502, 330-343.

Mongelli, G., Monni, S., Oggiano, G., Paternoster, M., Sinisi, R., 2013. Tracing groundwater salinization processes in coastal aquifers: a hydrogeochemical and isotopic approach in the $\mathrm{Na}-\mathrm{Cl}$ brackish waters of northwestern Sardinia, Italy. Hydrol. Earth Syst. Sci. 17, 2917-2928.

Murad, A.A., Garamoon, H., Hussein, S., Al-Nuaimi, H.S., 2011. Hydrogeochemical characterization and isotope investigations of a carbonate aquifer of the northern part of the United Arab Emirates. J. Asian Earth Sci. 40, 213-225.

Mutchler, T., Dunton, K.H., Townsend-Small, A., Fredriksen, S., Rasser, M.K., 2007. Isotopic and elemental indicators of nutrient sources and status of coastal habitats in the Caribbean Sea, Yucatan Peninsula, Mexico. Estuar. Coast. Shelf Sci. 74 (3), 449-457.

Null, K.A., Knee, K.L., Crook, E.D., de Sieyes, N.R., Rebolledo-Vieyra, M., HernándezTerrones, L., Paytan, A., 2014. Composition and fluxes of submarine groundwater along the Caribbean coast of the Yucatan Peninsula. Cont. Shelf Res. 77, 38-50.

Olsthoorn, T.N., 2008. Do a bit more with convolution. Ground Water 46 (1), 13-22.

Oster, H., Sonntag, C., Münnich, K.O., 1996. Groundwater age dating with chlorofluorocarbons. Water Resour. Res. 32, 2989-3001.

Plummer, L.N., Busenberg, E., 1999. Chlorofluorocarbons: tools for dating and tracing young groundwater. In: Cook, P., Herczeg, A. (Eds.), Environmental Tracers in Subsurface Hydrology. Kluwer Academic Publishers, Boston, pp. 441-478.

Plummer, L.N., Michel, R.L., Thurman, E.M., Glynn, P.D., 1993. Environmental tracers for age dating young ground water. In: Alley, W.M. (Ed.), Regional ground-water quality. Van Nostrand Reinhold, New York, pp. 255-294.

Plummer, L.N., Rupert, M.G., Busenberg, E., Schlosser, P., 2000. Ground Water 38 (2), 264-283.

Plummer, L.N., Busenberg, E., Cook, P.G., 2006. Principles of chlorofluorocarbon dating Use of Chlorofluorocarbons in Hydrology - A Guidebook. International atomic energy agency, Vienna, pp. 17-29 (Chapter 3).

Prinn, R.G., Weiss, R.F., Fraser, P.J., Simmonds, P.G., Cunnold, D.M., Alyea, F.N., O'Doherty, S., Salameh, P., Miller, B.R., Huang, J., Wang, R.H.J., Hartley, D.E., Harth, C., Steele,
L.P., Sturrock, G., Midgley, P.M., McCulloch, A., 2000. A history of chemically and radiatively important gases in air deduced from ALE/GAGE/AGAGE. J. Geophys. Res. 105 (D14), 17751-17792.

Schiavo, M.A., Hauser, S., Cusimano, G., Gatto, L., 2006. Geochemical characterization of groundwater and submarine discharge in the south-eastern Sicily. Cont. Shelf Res. 26, 826-834.

Sidle, W.C., 1998. Environmental isotopes for resolution of hydrology problems. Environ. Monit. Assess. 52, 389-410.

Song, Q.C., 2013. Status quo of seawater intrusion in Daweijia karst water source of Dalian, China. J. Chengdu Univ. Technol. (Sci. Technol. Ed.) 40 (3), 348-352 (in Chinese with English abstract).

Szynkiewicz, A., Rangel-Medina, M., Modelska, M., Monreal, R., Pratt, L.M., 2008. Sulfur isotope study of sulfate in the aquifer of Costa de Hermosillo (Sonora, Mexico) in relation to upward intrusion of saline groundwater, irrigation pumping and land cultivation. Appl. Geochem. 23, 2539-2558.

Urresti-Estala, B., Vadillo-Pérez, I., Jiménez-Gavilán, P., Soler, A., Sánchez-García, D. Carrasco-Cantos, F., 2015. Application of stable isotopes $\left(\delta^{34} \mathrm{~S}_{-} \mathrm{SO}_{4}, \delta^{18} \mathrm{O}-\mathrm{SO}_{4}, \delta^{15} \mathrm{~N}-\right.$ $\mathrm{NO}_{3}, \delta^{18} \mathrm{O}-\mathrm{NO}_{3}$ ) to determine natural background and contamination sources in the Guadalhorce River Basin (southern Spain). Sci. Total Environ. 506-507, 46-57.

Vengosh, A., Ben-Zvi, A., 1994. Formation of a salt plume in the Coastal Plain aquifer of Israel: the Be'er Toviyya region. J. Hydrol. 160, 21-52.

Vengosh, A., De Lange, G.J., Starinsky, A., 1998. Boron isotope and geochemical evidence for the origin of Urania and Bannock brines at the eastern Mediterranean: effect of water-rock interactions. 62 (19/20), 3221-3228.

Vengosh, A., Spivack, A.J., Artzi, Y., Ayalon, A., 1999. Geochemical and boron, strontium, and oxygen isotopic constraints on the origin of the salinity in groundwater from the Mediterranean coast of Israel. Water Resour. Res. 35 (6), 1877-1894.

Vengosh, A., Hening, S., Ganor, J., Mayer, B., Weyhenmeyer, C.E., Bullen, T.D., Paytan, A. 2007. New isotopic evidence for the origin of groundwater from the Nubian Sandstone Aquifer in the Negev, Israel. Appl. Geochem. 22, 1052-1073.

Werner, A.D., Bakker, M., Post, V.E.A., Vandenbohede, A., Lu, C., Ataie-Ashtiani, B. Simmons, C.T., Barry, D.A., 2013. Seawater intrusion processes, investigation and management: recent advances and future challenges. Adv. Water Resour. 51, 3-26.

Wu, Q., 1990. Study on the management model of karst groundwater system in Daweijia Dalian City. Site Investigation Science and Technology 1 pp. 23-27 (in Chinese with English abstract).

Wu, Q., Jin, Y.J., 1990. Characteristics of seawater intrusion in coastal karst groundwater system of Daweijia area, Dalian City. Geotechnical Investigation \& Surveying 3 pp. 43-44 (In Chinese with English abstract).

Wu, Q., Jin, Y.J., Li, D.A., Xia, Y.H., 1994. The mechanisms of seawater intrusion of karst groundwater system in Daweijia, Dalian City and the countermeasures of its control. Chin. J. Geol. Hazard Control 1, 64-68 (in Chinese with English abstract).

Yang, J.L., 2011. Hydrogeochemical Reactions in Seawater Intrusion Process in Daweijia Water Source Area, Dalian City (In Chinese with English abstract) Master's degree thesis Jilin University, Changchun, China, pp. 14-15.

Yechieli, Y., Starinsky, A., Rosenthal, E., 1992. Evolution of brackish groundwater in a typical arid region: Northern Arava Rift Valley, Southern Israel. Appl. Geochem. 7, 361-374.

Young, M.B., Gonneea, M.E., Fong, D.A., Moore, W.S., Herrera-Silveira, J., Paytan, A., 2008 Characterizing sources of groundwater to a tropical coastal lagoon in a karstic area using radium isotopes and water chemistry. Mar. Chem. 109, 377-394.

Zhang, H.P., Liu, E.K., Wang, D.S., Jia, Y.K., Sun, J.C., 1991. Composition of stable isotopes of precipitation and controlling factors in China. Bull. Institute of Hydrogeology and Engineering Geology CAGS 7 pp. 101-110.

Zhang, X.Y., Jiang, H., Zhang, Q.X., Zhang, X., 2012. Chemical characteristics of rainwater in northeast China, a case study of Dalian. Atmos. Res. 116, 151-160.

Zhao, T.S., 1991. Problems of karst groundwater development in littoral area and its ultimate control method. Chin. J. Geol. Hazard Control 4, 73-77 (in Chinese with English abstract).

Zhao, C.R., Yang, J.L., Xiao, G.Q., Du, D., Pan, T., Zhang, S.F., 2012. Hydrogeochemical reactions and hydrogeological model for seawater intrusion processes in the Daweijia water source area, Dalian City. Geol. Surv. Res. 35 (2), 154-160 (in Chinese with English abstract).

Zuber, A., Michalczyk, Z., Maloszewski, P., 2001. Report: great tritium ages explain the occurrence of good-quality groundwater in a phreatic aquifer of an urban area, Lublin, Poland. Hydrogeol. J. 9, 451-460.

Zuber, A., Weise, S.M., Motyka, J., Osenbrück, K., Różański, K., 2004. Age and flow pattern of groundwater in a Jurassic limestone aquifer and related Tertiary sands derived from combined isotope, noble gas and chemical data. J. Hydrol. 286, 87-112. 